\title{
Cenozoic seismic stratigraphy and tectonic evolution of the Algarve margin (offshore Portugal, southwestern Iberian Peninsula)
}

\author{
Fernando C. Lopes ${ }^{a, b, *}$, P.P. Cunha ${ }^{a}$, B. Le Gall ${ }^{\mathrm{c}}$ \\ a Departamento de Ciências da Terra, Univ. Coimbra, Largo Marquês de Pombal, 3000-272 Coimbra, Portugal

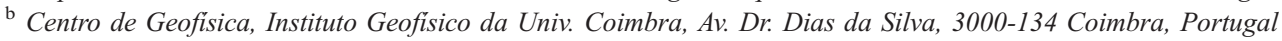 \\ c UMR 6538 CNRS, Institut Universitaire Européen de La Mer, Place Nicolas Copernic, 29280 Plouzane, France
}

Received 16 February 2005; received in revised form 23 May 2006; accepted 24 May 2006

\begin{abstract}
The Cenozoic seismic stratigraphy and tectonic evolution of the Algarve margin (southwestern border of the Iberian Peninsula) are documented from multichannel seismic reflection data, isochron and time-structure maps.

Six seismic units (B to G), bounded by unconformities and probably ranging in age from Campanian to Holocene, are identified. Their ages are derived from: 1) oil exploration wells drilled in the margin; 2) geometrical relationship with the Guadalquivir Allochthonous Unit; 3) correlation with the onshore stratigraphic record of the Algarve basin; and 4) lateral correlation with unconformities dated in adjacent basins and related to tectonic events that affected Iberia during the Cenozoic.

Three main tectonic domains, bounded by major fault zones that segment the Algarve margin, are characterised: a western central domain, bounded to the west by the N-S Portimão-Monchique Fault Zone and to the east by the N-S Albufeira Fault Zone; an eastern central domain, bounded to the east by the $\mathrm{N} 140^{\circ}$ São Marcos-Quarteira Fault Zone; and an eastern domain located east of this latter structure.

The Cenozoic evolution of the Algarve basin results from both Hercynian basement reactivation and thin-skinned contraction above a relative thick evaporitic unit (probably Upper Triassic-Hettangian) that acted as the main décollement, controlling synchronous extensional and thrust detachments and generating both salt structures and salt-withdrawal sub-basins. A persistent halokinesis is identified, with two climax phases: during the deposition of Unit C (Lutetian to Oligocene), and at Unit E (Upper Tortonian to Messinian). The increasing flexure of the Algarve margin is mainly expressed by spatial and temporal variations of the subsidence. The overall tectonic regime is considered to be compressive, and the close juxtaposition of compressed and extended areas is related to the orientation and geometry of preexisting basement tectonic structures and to the syncline evolution of the Guadalquivir foredeep basin in response to the westward migration of the Gibraltar Arc.
\end{abstract}

(C) 2006 Elsevier B.V. All rights reserved.

Keywords: Cenozoic; Algarve margin; seismic stratigraphy; halokinesis; tectonics

\footnotetext{
* Corresponding author. Departamento de Ciências da Terra, Univ. Coimbra, Largo Marquês de Pombal, 3000-272 Coimbra, Portugal.

E-mail addresses: fcarlos@ci.uc.pt (F.C.Lopes), pcunha@ci.uc.pt (P.P. Cunha), blegall@univ-brest.fr (B. Le Gall).
}

\section{Introduction}

The offshore Meso-Cenozoic Algarve basin is located on the southwestern margin of the Iberian Peninsula, just north of the Azores-Gibraltar Fracture Zone (AGFZ) that lies as the present day Africa/Eurasia plate western 
boundary (e.g. Srivastava et al., 1990a,b). It forms, together with the adjacent Spanish area, the northern border of the Gulf of Cadiz which is surrounded (Fig. 1): a) to the north, by the onshore Meso-Cenozoic Algarve basin $(130 \mathrm{~km} \times 20 \mathrm{~km})$, from the São Vicente cape to the Spanish border (Fig. 2); b) to the northwest, by the Alentejo margin; c) to the west, by the Gorringe Bank; d) to the south, by the Guadalquivir Bank and the Guadalquivir Allochthonous Unit; and e) to the northeast and east, by the SW Spanish margin, the Guadalquivir basin and the Betic orogenic belt.

The geodynamic evolution of the southern margins of Iberia during the Cenozoic has been controlled by the interaction between the Africa-Iberia convergence along the

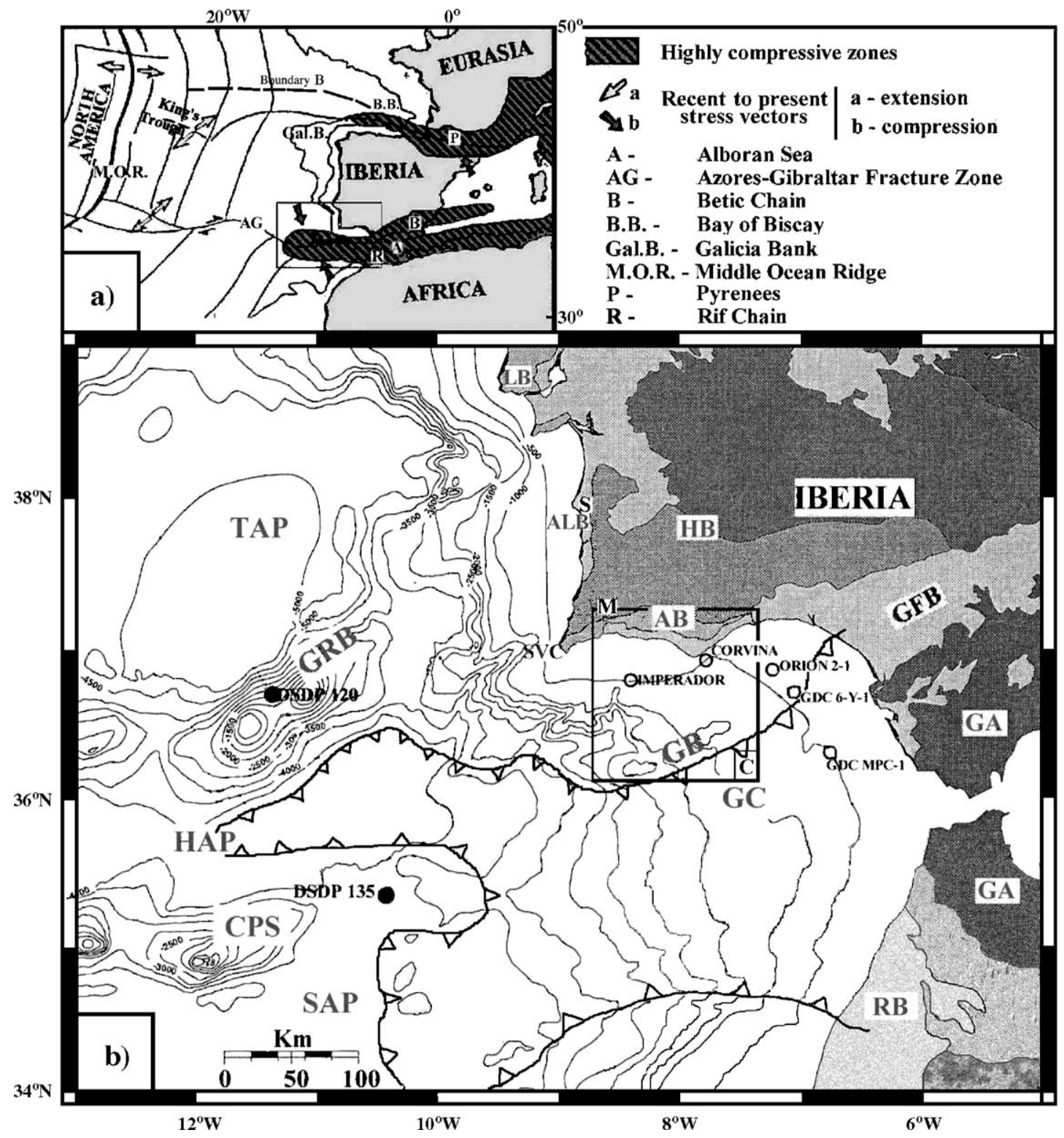

Fig. 1. (a) Present-day stress field at the periphery of the Iberian microplate (adapted from Olivet, 1996). (b) Geological setting and simplified bathymetry of the Gulf of Cadiz and surrounding areas. AB - Algarve basin; ALB - Alentejo basin; CPS — Coral Patch seamont; GA — Gibraltar Arc; GB - Guadalquivir Bank; GC — Gulf of Cadiz; GFB - Guadalquivir foreland basin; GRB — Gorringe Bank; HAP — Horseshoe Abyssal Plain; HB - Hercynian basement; LB — Lisboa basin; M — Monchique massif; S — Sines massif; SAP — Seine Abyssal Plain; SVC — SãoVicente Cape; TAP — Tagus Abyssal Plain; closed dots - DSDP sites; open dots — some exploration wells; solid line with open triangles — allochthonous front (adapted from Le Gall et al., 1997; Tortella et al., 1997). (C) Study area. 
eastern segment of the AGFZ (Dewey et al., 1989; Srivastava et al., 1990a,b) and the westward migration of the Gibraltar Arc, which represents the structural closure of the Alpine belts of southern Iberia and northern Africa (e.g. Sanz de Galdeano, 1990; Sanz de Galdeano and RodríguezFernández, 1996; Maldonado et al., 1999; Gràcia et al., 2003). As a consequence, the structure of these margins is very complex; they relate to the westernmost segment of the Alpine orogeny but also record the phases that lead to the opening of the Atlantic Ocean and (Paleo)-Mediterranean Sea and the closure of the Tethys.

Many clues about the Cenozoic evolution of the Algarve margin are supplied by multichannel seismic reflection (MCS) data (64 profiles), gravity data, and five commercial exploration wells, recorded during the early seventies to eighties; these help to define the stratigraphic and structural characteristics of the Cenozoic sedimentary cover.

The seismic stratigraphy and some structural features of the Algarve margin were previously considered by Mougenot (1989) and Terrinha (1998a,b). More recently, from a detailed interpretation of the available seismic, gravity and seismological dataset, the Cenozoic history of the Algarve margin was more precisely defined (Lopes et al., 1999; Baptista et al., 2000; Lopes and Cunha, 2000; Lopes, 2002). The main goal of the present paper is to give an accurate summary of the overall tectono-stratigraphic evolution of the Algarve Cenozoic margin in the geodynamic context of the Africa-Eurasia plate boundary.

\section{Geological setting}

From $14^{\circ} \mathrm{W}$ to the Gibraltar Strait, which corresponds to the eastern end of the AGFZ, the plate boundary is not well defined and the African/Europe convergence is accommodated through a widespread tectonically active deformation zone (e.g. Sartori et al., 1994), where a significant and diffuse seismic activity has long been recognised (Fukao, 1973; Udías et al., 1976; Grimison and Chen, 1986; Buforn et al., 1988, 1995). Tortella et al. (1997) subdivided this area in two main morphological

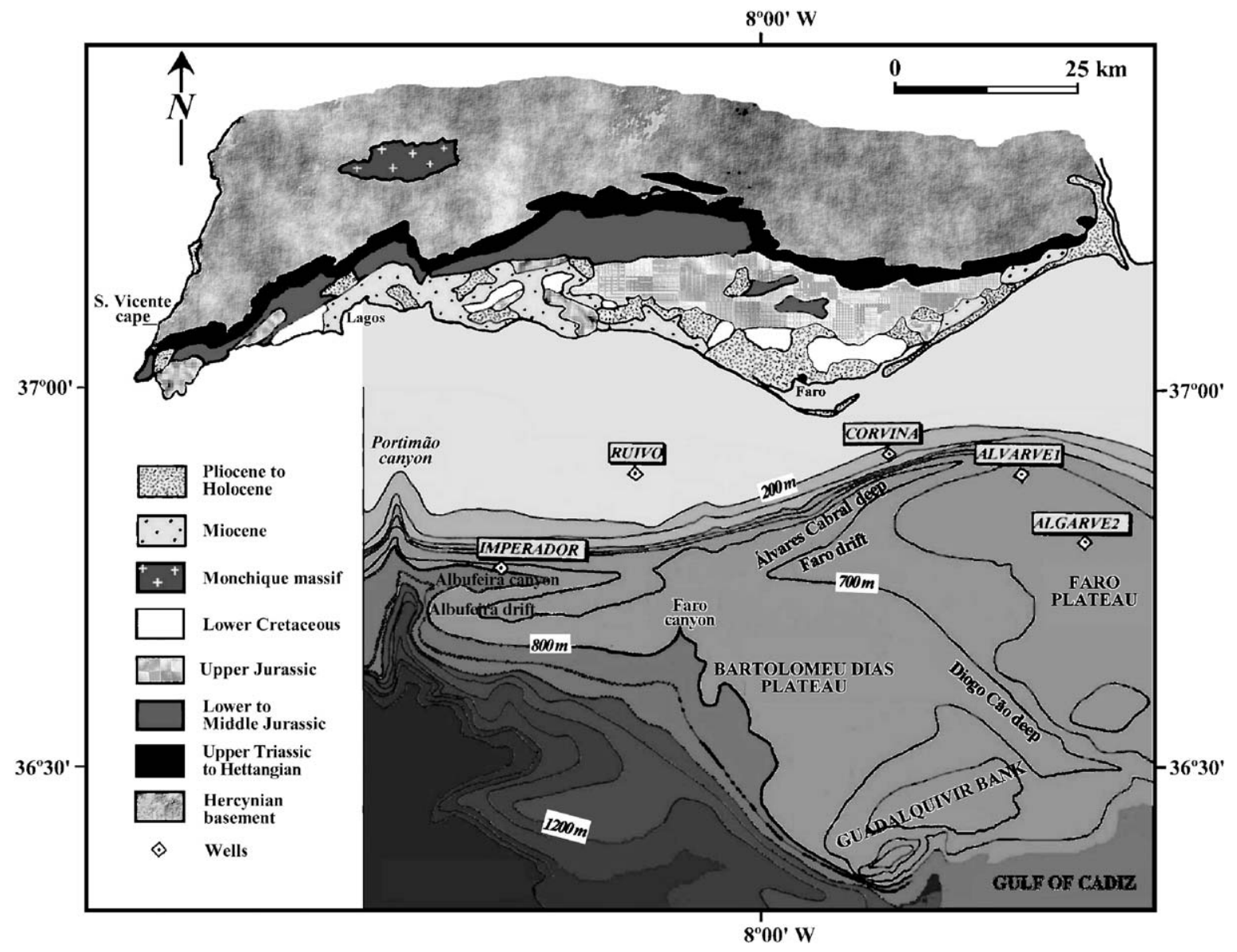

Fig. 2. Simplified map integrating the onshore geology features and the bathymetry of the study area. 
domains comprising: a) to the west, the Gorringe Bank domain underlain by oceanic crust between the Gorringe Bank and the São Vicente cape; and b) to the east, between the São Vicente cape and the Gibraltar Strait, the Gulf of Cadiz domain, underlain by Hercynian continental crust (González et al., 1998) and bounded to the north by the Algarve and Spanish continental margins.

Since the Late Cretaceous, at the onset of Alpine compression (Olivet, 1996), the geodynamic evolution of the Gulf of Cadiz was primarily controlled by: 1) the interaction of the Iberian and African plates, whose relative motion became convergent, and 2) the westerly migration of the South Sardinian Domain (e.g. Sanz de Galdeano, 1990), forming the Betic-Rif Cordillera. From pre-Early Langhian to Late Tortonian, concentric wedges of fold-thrust belts (Campo de Gibraltar, External Betics; Guadalquivir Allochthonous) were emplaced in the Gulf of Cadiz, expelled from the frontal sector of the Gibraltar Arc (Gràcia et al., 2003). The structural complexity of this lithospheric-scale compressive system was registered in the Cenozoic depositional history of the southern border of Iberia, namely the Algarve and SW Spanish continental margins, where two main tectonic events are well documented in connection with rejuvenation and inversion of basement normal faults.

In Lutetian (chron 18; $42 \mathrm{Myr}$ ) (Roest and Srivastava, 1991), the Gulf of Cadiz was affected by a major N-S compression (i.e. Lutetian compressive phase; Mougenot, 1989; Cunha, 1992a,b) that resulted in: a) the cessation of movement along the boundary B (Fig. 1), and the jumping of the plate boundary to the extended region of King's Trough, extending eastward along the Azores-Biscay to the North-Spanish Trough and shortened Pyrenees (Srivastava et al., 1990a,b; Roest and Srivastava, 1991), and b) the reactivation of the Azores-Gibraltar fracture zone that constituted again a plate boundary between Africa and Iberia; this latter starting to move as an independent plate (Roest and Srivastava, 1991). According to Maldonado et al. (1999), the transpressive movement between Iberia and Africa along the Gulf of Cadiz was

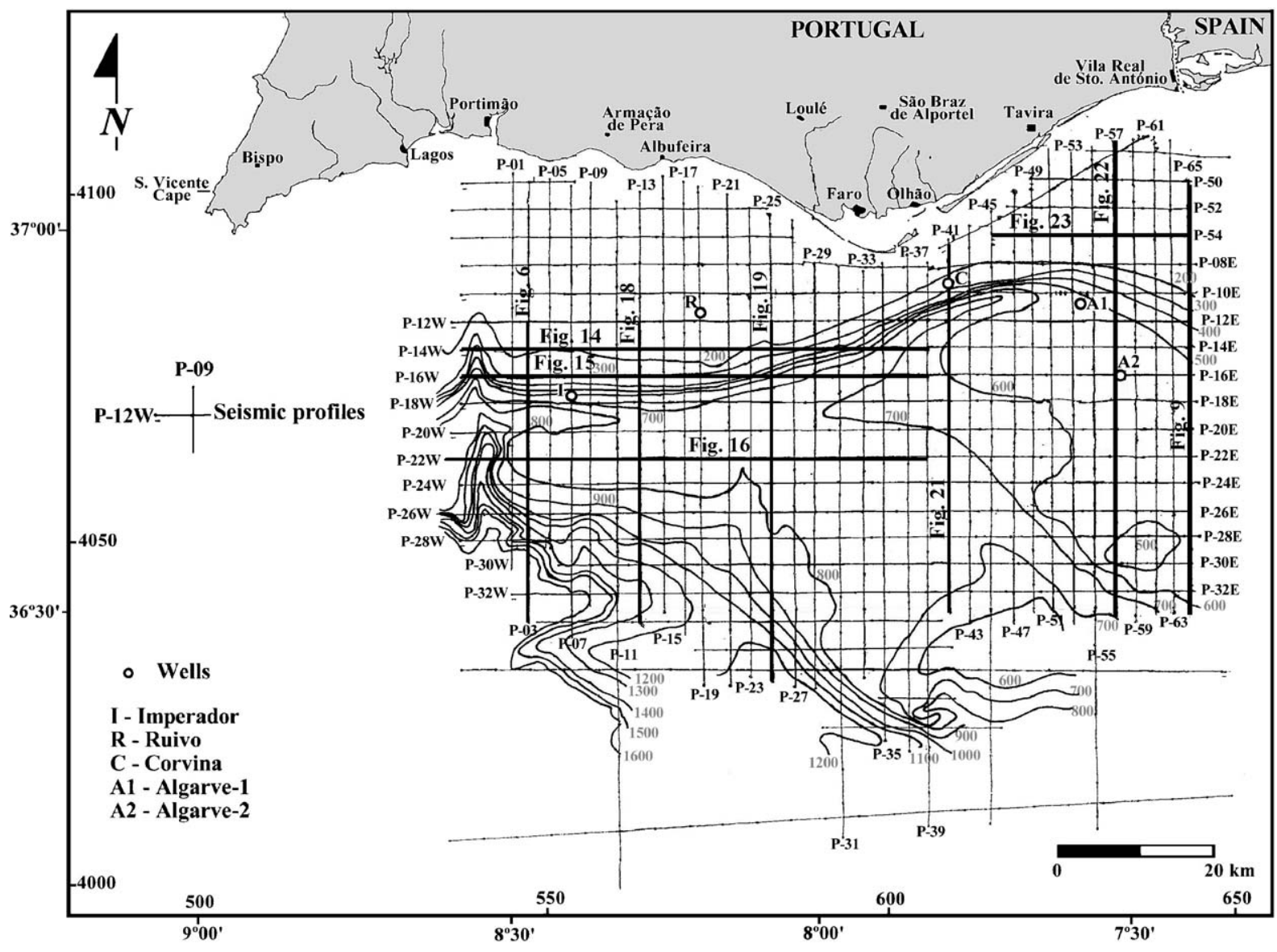

Fig. 3. Simplified bathymetric map of the study area, showing the grid of multichannel seismic (MCS) profiles and five oil exploration wells in the Algarve margin. Solid lines with numbers indicate the MCS profiles showed in this paper. 


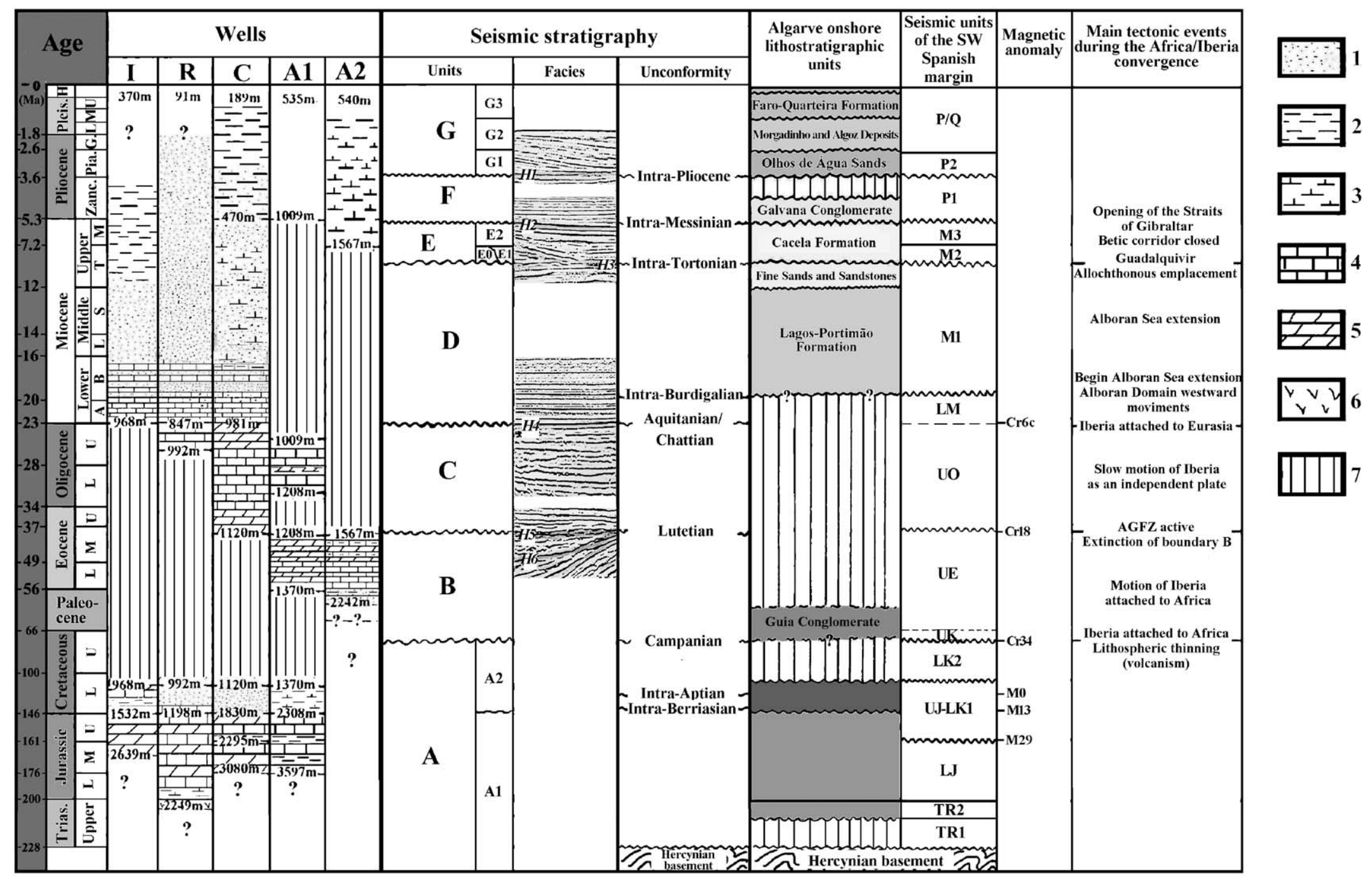

Fig. 4. Seismic stratigraphy, main unconformities and wells in the Algarve offshore. Wells: I - Imperador-1; R - Ruivo-1; C - Corvina-1; A1 - Algarve-1; A2 - Algarve-2. 1 - sands; 2 clays; 3 - silts; 4 - limestones; 5 - dolomites; 6 - evaporites; 7 - hiatus. Cenozoic seismic units and bounding unconformities are correlated to the onshore lithostratigraphic units (Pais et al., 2000) and to the seismic units of SW Spanish margin (Maldonado et al., 1999). The tectonic events and relative motion of Iberia and Africa are correlated with the development of the seismic units. 
initiated in the Lutetian, with the probable subduction of the Tethys thinned crust towards the south. This initially slow movement has become more rapid since anomaly 13 (Early Oligocene).

In the Middle Tortonian, the Gulf of Cadiz and Betic areas registered a second highly compressive event, oriented NNW-SSE to NW-SE, as a result of the convergence between Africa and Iberia, and due to the slowing up of the movement west of the Internal Zones and to the end of extension throughout the Alboran Sea (Sanz de Galdeano, 1990; Sanz de Galdeano and Vera, 1991; Sanz de Galdeano and Rodríguez-Fernández, 1996; Maldonado et al., 1999; Gràcia et al., 2003). This event coincided with the last major radial expulsion of the External Zones (Prebetics and Flysch Basin), coeval with the stretching of the Internal Zones, leading to the disappearing of the Betic North Strait; this became restricted to the western sector of the Betic trough (Sanz de Galdeano and Vera, 1991). This event also corresponds to the development of most of the Betic Neogene basins (Sanz de Galdeano and Vera, 1991) and to the emplacement of the Guadalquivir Allochthonous Unit in the South Iberian margin and in the central part of the Gulf of Cadiz, (Gràcia et al., 2003). Some Mesozoic and Cenozoic fragments of the Betic margin were included here in response to the action of imbricated thrusts and low-angle detachments (Bonnin et al., 1975; Lajat et al., 1975; Malod, 1982; Sanz de Galdeano, 1990; Flinch et al., 1996; Maldonado et al., 1999; Maestro et al., 2003). Gravity processes were largely responsible for the migration of the allochthonous unit front towards the Horseshoe and Seine abyssal plains during Late Miocene and early Middle Pliocene (Torrelli et al., 1997; Maestro et al., 2003), forming the Giant Chaotic Body (Gràcia et al., 2003). In the Betic margin, large masses of Triassic-Hettangian evaporites, probably extruded by the tectonic load of thrust sheets directed towards the foreland (Berástegui et al., 1998), were responsible for important halokinesis in the central part of the Gulf since the Messinian (Flinch et al., 1996). On the Portugal mainland, evidence for Late Miocene NNW-SSE regional compression is observed in the post-Palaeozoic sedimentary basins (thin-skinned), as well as in the Hercynian Massif (thick-skinned) (Ribeiro et al., 1990). At the SW Iberian margin, this phase of intense instability was responsible for some significant uplift in the Gorringe Bank (Le Gall et al., 1997). According to Alves et al. (2003), the third Cenozoic deformation event affecting the Alentejo margin relates to the Late Tortonian-Zanclean tectonics and is responsible for the initiation of the modern Setúbal and São Vicente submarine canyons.

The present-day arcuate outward-directed Betic-Rif mountain belt (Maldonado et al., 1999): a) the subsidence of the Alboran Domain; b) the accretionary eastwardthickening wedge of the allochthonous unit in the Gulf of Cadiz; and c) the intermediate to deep-depth seismicity beneath the Gibraltar Arc, westernmost Alboran Sea and southern Spain (Casado et al., 2001), are all consistent with an active east-dipping subduction zone beneath the Gibraltar Arc (Gutscher et al., 2002).

\section{Data and methodology}

The study area $(100 \times 80 \mathrm{~km})$ covers the central and eastern part of the Algarve continental margin in southern Portugal (Fig. 2).

The dataset comprises a network of sixty four nonmigrated multichannel seismic reflection (MCS) profiles located between Portimão and Vila Real de Santo António

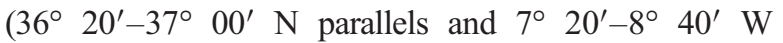
meridians), covering $7700 \mathrm{~km}^{2}$ in the central and eastern sectors of the margin (Fig. 3). Two sets of E-W and N-S seismic lines (regular interval of ca. $3 \mathrm{~km}$ ), with a mean length of ca. $100 \mathrm{~km}$ and a TWT vertical scale of $4 \mathrm{~s}$, allow the construction of isopach maps for each identified seismic stratigraphic unit. Six main Cenozoic seismic units, with internal subunits, are recognised from seismic data interpretation, following the methodology of Mitchum et al. (1977) and Mitchum and Vail (1977). From Upper Cretaceous to Holocene, the seismic units are referred to as $\mathrm{B}$ to $\mathrm{G}$ and their boundaries are labelled as reflectors $H 6$ to $H 1$. Their ages are constrained by: 1 ) some biostratigraphic data from five oil exploration wells, as deep as $3 \mathrm{~km}$, drilled in the central and eastern sectors of the Algarve margin, and named as follows: Imperador-1 (1976), Ruivo-1 (1975), Corvina-1 (1976), Algarve-1 (1982), Algarve-2 (1982); 2) calibration with an adjacent Spanish MCS profile (Maldonado et al., 1999) that intersects the Portuguese seismic grid under study; 3) lateral correlation with the Guadalquivir Allochthonous front, dated to the Middle to Late Tortonian in an adjacent area (e.g. Gràcia et al., 2003); and 4) correlation with dated unconformities in adjacent Portuguese basins (Cunha, 1992a,b; Pais et al., 2000; Alves et al., 2003).

\section{Basin stratigraphy}

The southwestern border of the Iberian Peninsula is a fragment of the Hercynian external orogen, the South Portuguese Zone (SPZ; Lotze, 1945), comprising an arched fold/low-angle thrust belt overlain by the Mesozoic-Cenozoic series of the Algarve basin. First-phase fold axes are predominantly NNW- to SSE-oriented, but second-phase structures show a NW to SE trend (Pinheiro et al., 1996). The basement is cross-cut by Late Hercynian 
faults, with NNW-SSE to NW-SE and ENE-WSW dominant strikes that subsequently exerted a pronounced structural control on the Mesozoic rift geometry of the Algarve basin, as documented for other basins of Iberia (Ribeiro et al., 1979).

The sedimentary record in the $140-\mathrm{km}$ long and E-Wtrending Algarve basin continues through the Betic Cordillera foreland (Pre-Betic Zone), belonging to the western Tethys margins (Fig. 1). The larger part of the Algarve basin is located offshore, with its southeastern boundary coinciding with the Guadalquivir Bank and the Guadalquivir Allochthonous front. It is made up of a number of evolving depocentres that are bounded either by salt structures or by major faults that define main tectonic domains. The dominant sets of faults are $\mathrm{N}-\mathrm{S}$, NW-SE and NE-SW; Cenozoic thrusts strike predominantly ENE-WSW. The presence of huge evaporite complexes, probably Triassic-Hettangian in age, influenced the tectonic style of the younger sedimentary cover, acting as a décollement during the extensional and compressional movements affecting Hercynian basement faults (Ribeiro et al., 1990; Pinheiro et al., 1996; Terrinha, 1998a,b; Lopes, 2002).

The stratigraphical record of the Algarve basin is thought to span from Triassic to Holocene, with several main unconformity-bounded sequences (Terrinha, 1998a, b; Lopes and Cunha, 2000; Lopes, 2002; Fig. 4).The Triassic to Toarcian units (e.g. Palain, 1976; Manuppella, 1988), typical of the early rift-sag successions encountered in most North Atlantic margin basins (Ziegler, 1989), are about $500 \mathrm{~m}$ thick onshore. The Triassic red fluvial siliciclastics are capped by Hettangian pelite-carbonateevaporite complexes and volcano-sedimentary series, followed by Lower Jurassic dolomites and marly limestones. Offshore, Ruivo-1 well bottoms in Triassic rocks composed mainly of anhydrite with minor beds of clays and salt (Fig. 4).

The Aalenian-Calovian units are up to $960 \mathrm{~m}$ thick offshore and $500 \mathrm{~m}$ thick onshore; they comprise Aalenian to Bajocian bioclastic limestones that change upwards into marls and limestones. The Oxfordian to Lower Berriasian deposits (about 1000 m thick) include Oxfordian to Kimeridgian dolomites and limestones, and Tithonian-Lower Berriasian limestones.

The onshore Cretaceous series spans from the Berriasian to the Cenomanian and is divided into three groups (e.g. Rey, 1982, 1983; Manuppella, 1988; Correia, 1989; Berthou and Lereveld, 1990). The dominant lithologies are (1) limestones, (2) sandstones and clays, and (3) clays in the western, central and eastern groups, respectively. The sedimentary record of the Upper Cretaceous-Paleocene boundary is rare and locally represented by the Guia
Conglomerate (Manuppella, 1988, 1992; Pais, in press). The Upper Berriasian to Albian sediments identified offshore reach $900 \mathrm{~m}$ in thickness, comprising dolomites, sandstones and interbedded limestones and marlylimestones.

Paleogene sediments have been reported from the offshore wells but seem to be absent onshore. The Upper Campanian (?) to Lutetian sequence is $675 \mathrm{~m}$ thick, made up of dolomites and some limestones. The Lutetian to Oligocene sequence is $200 \mathrm{~m}$ thick, comprising micritic limestones and minor dolomites.

Miocene sediments are well represented in the Algarve basin. Offshore, probable Aquitanian to Lower Tortonian deposits are inferred to be $100 \mathrm{~m}$ thick and made up mainly of limestones overlaid by fine sandstones. They correlate onshore with the Lagos-Portimão Formation (Antunes et al., 1981), dated from Lower Burdiglian to Upper Serravalian (Antunes et al., 1981, 1984; Antunes and Pais, 1992; Cachão, 1995; Antunes et al., 1997; Pais et al., 2000) and only represented in the western and central Algarve. These deposits are overlain by the Lower Tortonian "Fine Sands and Sandstones" unit (Antunes et al., 1997; Pais et al., 2000). The uppermost Tortonian to Messinian sediments are dominantly siltites (Cacela Formation; Antunes and Pais, 1992; Antunes et al., 1981, 1984; Cachão, 1995; Antunes et al., 1997; Pais et al., 2000) occurring mainly in the eastern Algarve.

The Pliocene and Holocene onshore deposits (Olhos de Água Sands; Morgadinho and Algoz Deposits; Ludo Formation; Faro-Quarteira Formation; e.g. Antunes et al., 1986; Moura and Boski, 1994, 1999; Pais et al., 2000) are thin (30 m thick) siliciclastic outcropping extensively along the coastline. The uppermost Tortonian to Holocene offshore deposits can reach $1000 \mathrm{~m}$ thick and are almost all siliciclastic (marine siltstones and sandstones).

Two peaks in Meso-Cenozoic magmatic activity are expressed by: a) basaltic lavas and tuffs, of Upper TriassicHettangian age, and b) Middle Campanian alkaline pluton intrusions (MacIntyre and Berger, 1982), occurring onshore in the Sintra, Sines and Monchique areas, probably along a deep-seated dextral strike-slip fault (e.g. Ribeiro et al., 1979; Terrinha, 1998a; Terrinha et al., 1999).

\section{Seismic stratigraphic units}

From the analysis of the seismic sequence, seven stratigraphic units $(A-G)$ were identified (discussed below). The boundaries of these units are marked by reflectors that represent major unconformities. Unit A comprises the Hercynian basement and the Carnian to Middle Cretaceous succession (Fig. 4). The Mesozoic is more than $1.8 \mathrm{~s}$ TWTT in thickness. This seismic unit 
shows internal diffractions and some continuous high amplitude reflectors. Despite difficulties dealing with the seismic resolution, two subunits separated by an unconformity can be identified in some places: a lower subunit (A1) pre-Cretaceous in age, and an upper subunit (A2), Lower to Middle Cretaceous in age.

This paper only focuses on units ranging from $B$ to $G$ and shown on the simplified stratigraphic chart of Fig. 4.

\subsection{Unit B (Upper Campanian to Lutetian)}

The lower boundary of Unit B is a strong but discontinuous reflector (H6 reflector) truncating Unit A. Unit B seems to fill syncline structures and is best developed in the eastern sector of the Algarve margin where it can reach more than $0.4 \mathrm{~s}$ TWTT thickness (Fig. 5). This unit shows a variable and irregular internal reflection pattern characterised by chaotic zones, alternating with subparallel, discontinuous, middle to high-amplitude and low-frequency reflectors. These structures baselap onto the $H 6$ reflector and contact with the $H 5$ reflector through an erosional truncation. The geometry and seismic character of this unit suggest intense post-sedimentary deformations.

Algarve-1 and Algarve-2 wells show that marls and sandstones occur at the base of Unit B whereas the upper part is composed of marine grey dolomites intercalated with marly limestones and micritic limestones.

The H6 reflector could represent the Campanian unconformity, documented in other Portuguese areas (Mougenot, 1981, 1989; Cunha and Pena dos Reis, 1995), and related to the incipient Africa/Iberia convergence (Dewey et al., 1973; Srivastava et al., 1990a,b; Roest and Srivastava, 1991). Unit B may correlate onshore with the Guia Conglomerate of the Algarve onshore and with Unit UK-UE of the SW Spanish margin (Maldonado et al., 1999).

\subsection{Unit C (Lutetian to Oligocene)}

The lower boundary of Unit C is recorded by a very strong high-amplitude reflector (H5) that represents an angular or erosional unconformity (profile P-03; Fig. 6).

Unit $C$ is present throughout the study area with lateral thickness changes reaching more than $0.6 \mathrm{~s}$ TWTT in halfgrabens and foredeep basins mainly at the eastern Algarve margin. The temporal isopach data (Fig. 7) document a widespread development of multiple fault- and salt structure-bounded depocentres. This unit is generally characterised by a sequence of high-amplitude, lowfrequency and subparallel reflectors, displaying a high lateral continuity, which onlap the underlying units landwards. Divergent reflection patterns occur within half-graben structures, synclines and salt withdrawal subbasins. Chaotic reflectors occur locally, on the flanks of salt structures and in fault zones. The general geometry and seismic facies, calibrated by well data (Imperador, Ruivo-1, Corvina and Algarve-1), typify micritic limestones developed in a marine carbonate platform environment.

Seismic data show that the Lutetian to Oligocene evolution of the Algarve margin is characterised by an intense and widespread halokinesis, resulting in a salt-/ fault-controlled (thin-skinned) subsidence that greatly influence the thickness and lateral distribution of Unit C.

No lateral equivalent of Unit $\mathrm{C}$ is known in the Algarve onshore. However, this unit seems to be correlated with the Unit UO-LM described by Maldonado et al. (1999) in the adjacent SW Spanish margin and with the C10 seismic sequence proposed by Alves et al. (2003) in the Alentejo basin. The H5 reflector could represent the Lutetian unconformity dated in central Portugal (e.g. Cunha, 1992a, b), and is probably related to the reactivation of the AGFZ as a plate boundary between Africa and Iberia during Lutetian (chron 18, ca. 42 Myr; Srivastava et al., 1990a,b; Roest and Srivastava, 1991; Maldonado et al., 1999).

\subsection{Unit D (Aquitanian to Lower Tortonian)}

The lower boundary of Unit D is a high-amplitude reflector $(H 4)$ corresponding to a regional unconformity. The biostratigraphic report of Ruivo-1 well indicates that the Oligocene-Miocene boundary is located at $823 \mathrm{~m}$-depth (below sea-level) (Fig. 4), e.g. at a depth of $0.740 \mathrm{~ms}$ TWTT that coincides with the $H 4$ reflector in profile P-19 MCS. Therefore, the age of the unconformity between units $\mathrm{C}$ and $\mathrm{D}$ is probably Chattian/Aquitanian. However, the later increase in siliciclastics documented by the Imperador, Ruivo-1 and Corvina wells, but not evidenced by a seismic reflector, could be a sedimentary response to the intraBurdigalian Betic event (Sanz de Galdeano, 1990). The DSDP site 135 documents a hiatus between Ypresian and Upper Oligocene (Hayes et al., 1972); the DSDP site 120 shows a hiatus between Lower Cretaceous and the Oligocene/Miocene boundary (Ryan et al., 1973). According to Alves et al. (2003) the Alentejo margin was deformed in Chattian and an unconformity was generated.

Unit D is widespread and exhibits variable seismic facies across the study area, reaching more than $0.25 \mathrm{~s}$ TWTT in thickness (Fig. 8) and generally characterised by two seismic facies. In the northern area, landwards, the lower part of this unit shows an internal reflection pattern that consists of subparallel continuous reflectors of medium to high-amplitude and moderate frequency. 


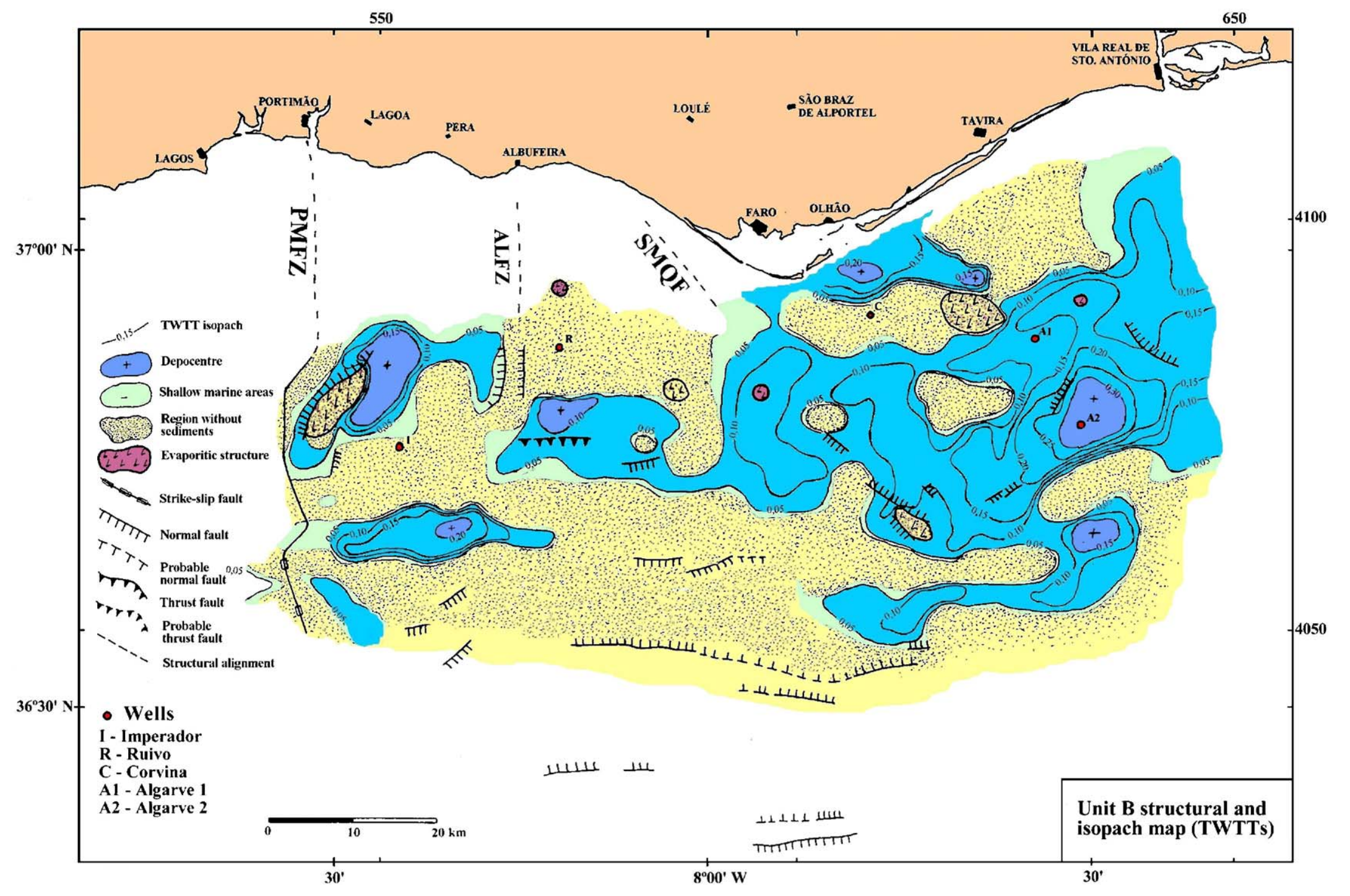

Fig. 5. Unit B structural and isopach map (TWTTs). PMFZ — Portimão-Monchique Fault Zone; ALFZ — Albufeira Fault Zone; SMQF — São Marcos-Quarteira Fault Zone. 
TWTT(S)

TWTT(S)

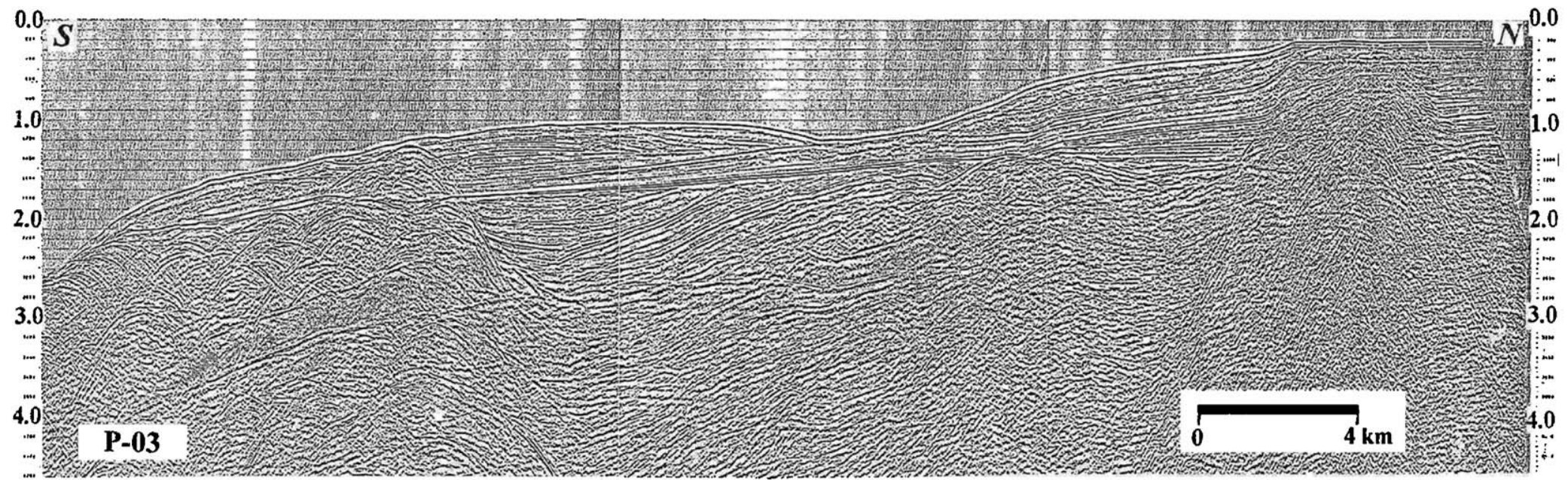

TWTT(S)

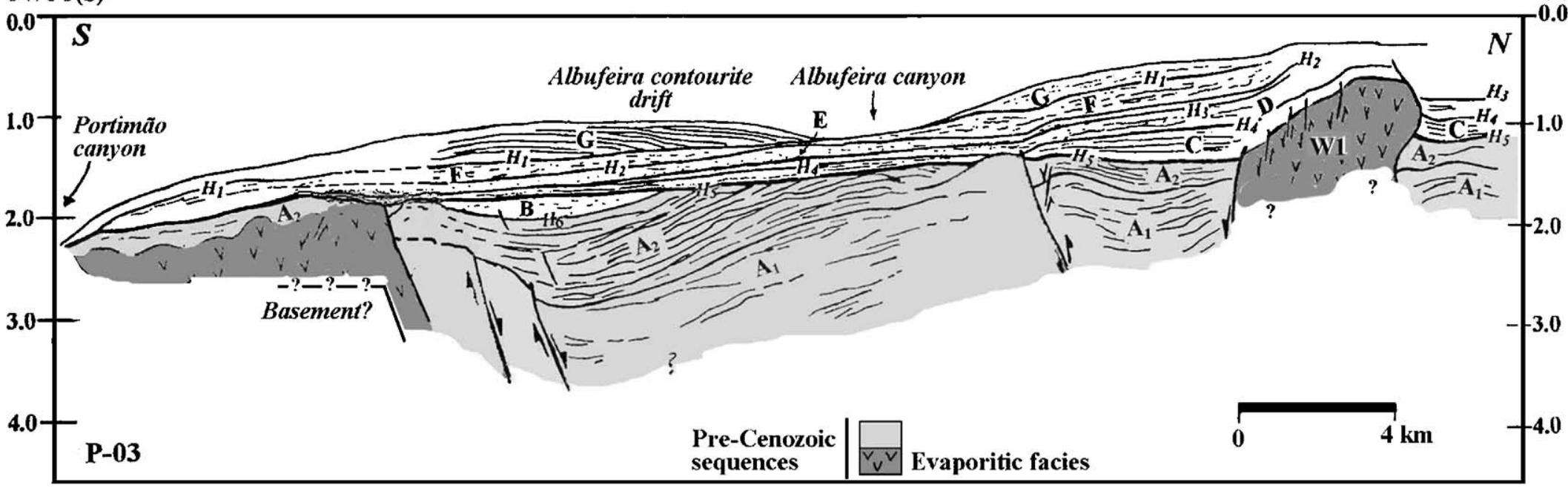

Fig. 6. P-03 seismic profile and corresponding interpretation (see Fig. 3 for location). The $H 5$ reflector corresponds to an angular unconformity. Some organized reflections are evident beneath $H 6$ allowing that a prograding shelf to be identified in the subunit A2 


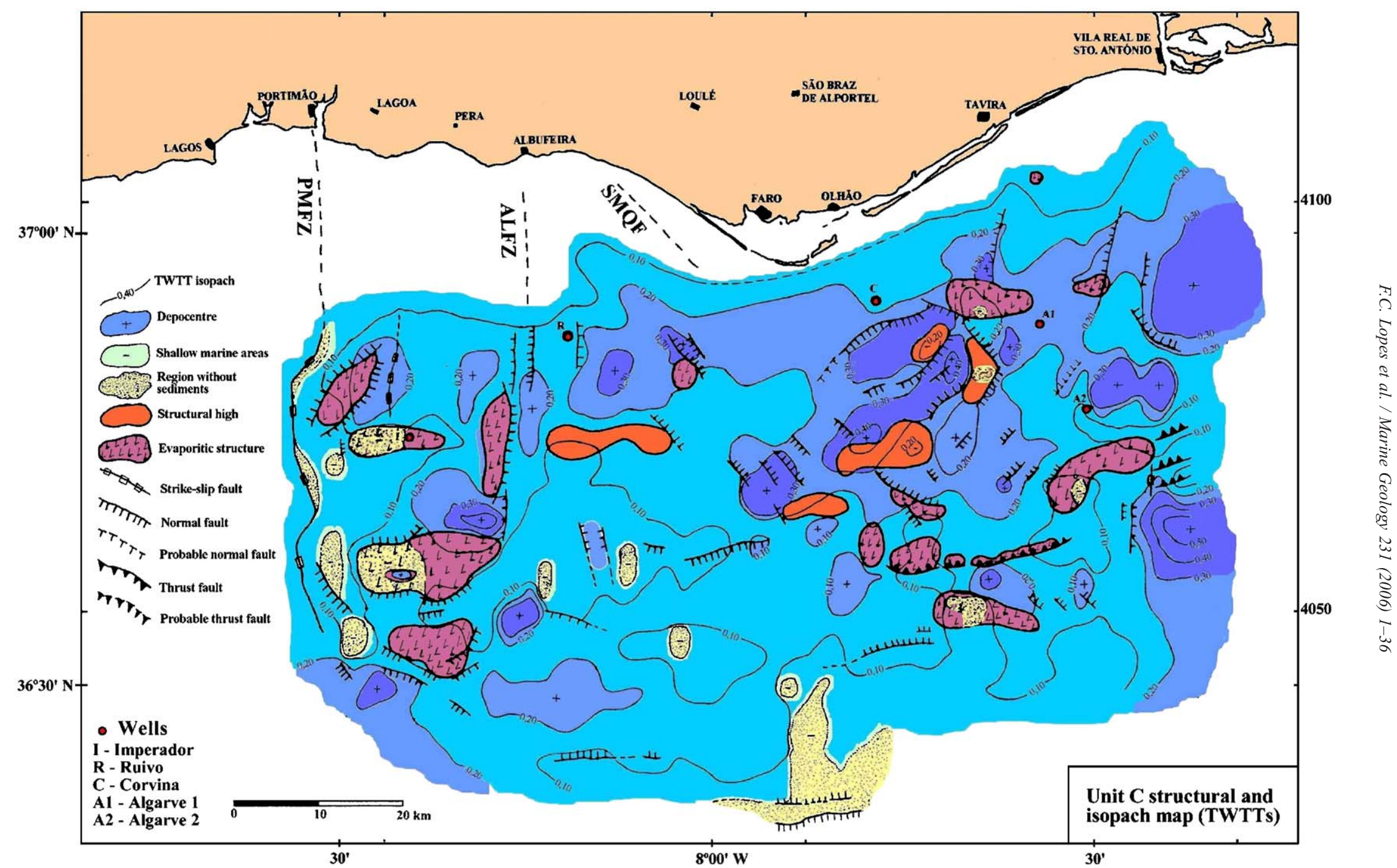

Fig. 7. Unit C structural and isopach map (TWTTs). PMFZ — Portimão-Monchique Fault Zone; ALFZ — Albufeira Fault Zone; SMQF — São Marcos-Quarteira Fault Zone; TF — thrust front; FDB - foredeep basin; ITB - imbricated thrust belt. 
These reflectors are observed to onlap landwards and downlap to baselap basinwards. The upper part exhibits hummocky clinoform reflection configurations. The well data indicate that Unit D has a main carbonate character downwards, passing upwards into a siliciclastic character (Fig. 4). Moreover, this facies evolution does not seem to occur basinwards, where the carbonate character is predominant. Well data are consistent with these seismic facies. Chaotic reflections occur on the flanks of salt structures and in fault zones.

Unit $\mathrm{D}$ is not recognised in a number of specific areas: a) a narrow $30-\mathrm{km}$ long $\mathrm{N}-\mathrm{S}$ trending zone at the western end of the study area; b) an E-W trending zone at $12 \mathrm{~km}$ south of the Imperador well site; c) some places in the central part of the area; d) a $15-\mathrm{km}$ wide $\mathrm{N}-\mathrm{S}$ trending zone at the northeastern extremity of the study area, between Tavira and Vila Real de Santo António, and extending southwards into the Algarve-1 and Algarve-2 well sites (Fig. 8).

Halokinesis was relatively moderate during the deposition of Unit D, as shown by the minor sedimentary growth on the flanks of salt structures.

The lower and middle parts of Unit D are inferred to correlate onshore with the Lagos-Portimão Formation, dated as Lower Burdigalian to Upper Serravallian. The upper part of Unit D is characterised by a predominant siliciclastic facies that can be correlated with the Fine Sands and Sandstones unit (Lower Tortonian) overlying the Lagos-Portimão Formation. Unit D seems to be equivalent to the LM and M1 units identified in the SW Spanish margin by Maldonado et al. (1999) and also to the M1, M2 and S1 units of Alves et al. (2003) in the Alentejo basin (Fig. 1).

\subsection{Unit E (Upper Tortonian to Messinian)}

The lower boundary of Unit $\mathrm{E}$ is a moderate to highamplitude reflector (H3) marking the base of the Guadalquivir Allochthonous front. Southeastwards, near the allochthonous front, this boundary constitutes a very high-amplitude reflector that corresponds to a widespread erosional unconformity. From seismic profiles, three subunits can be identified (Fig. 9): subunit E0 is the Guadalquivir Allochthonous front; subunit E1 is only recognised in the southeastern Algarve margin, near the allochthonous front; subunit E2 is a widespread sequence overlying either subunits E0/E1 (southeastern Algarve margin) or Unit D.

Unit E is tied laterally with the Upper TortonianMessinian Cacela Formation. Two lower members of this formation were identified in the eastern onshore Algarve as the "Auramar conglomerate" and the "Faro limestones with quartz pebbles and conglomerates" (Pais et al.,
2000). Unit E may be correlated to Unit $\mathrm{S} 2$ in the Alentejo basin (Alves et al., 2003).

\subsubsection{Guadalquivir Allochthonous front - subunit EO (Upper Tortonian)}

The southeastern end of the study area (Figs. 9 and 10) is dominated by a huge, $50-\mathrm{km}$ wide and wedge-shaped, allochthonous sedimentary body, pinching out northwards and westwards. This subunit represents the northward prolongation of the Guadalquivir Allochthonous front which covers a considerable part of the Gulf of Cadiz (e.g. Gràcia et al., 2003). It is characterised by a chaotic seismic facies with high-amplitude reflection pattern, showing diffractions and hyperbolic reflections. Its lower boundary is the very high-amplitude reflector $H 3$, dipping southeastwards from the allochthonous unit front and becoming obscure below it. High-amplitude reflectors within the allochthonous body may correspond to low-angle overthrust planes.

The emplacement of the Guadalquivir Allochthonous Unit ended in the Late Tortonian (Gràcia et al., 2003), just before the deposition of subunit E1.

\subsubsection{Subunit E1 (Upper Tortonian)}

Subunit E1 is only evidenced near the allochthonous front as a wedge-shaped body that interfingers with it (Fig. 9). Its thickness decreases uniformly northwards and westwards from the allochthonous front, reaching $0.4 \mathrm{~s}$ TWTT. Its seismic facies is generally characterised by a sequence of high-amplitude and continuous reflectors with low frequency, which change upwards into moderate to low-amplitude continuous reflectors with moderate frequency. These reflectors suggest progradational configuration patterns, downlapping against $H 3$. Chaotic reflections also occur: 1) near the allochthonous front, into some small depressions on top of the Guadalquivir Allocthonous unit, which may be filled by this subunit; and 2) northwards from the allochthonous front, on the southern flank of the salt wall associated with an $\mathrm{E}-\mathrm{W}$ trending thrust front.

The seismic facies suggests that detrital deposits occur near the front of the allocthonous unit, grading northwards into pelagic deposits.

Subunit E1 is considered as equivalent to the Unit M2 described in the SW Spanish margin by Maldonado et al. (1999).

\subsubsection{Subunit E2 (Messinian)}

Subunit E2 is a widespread sequence separated from the subunit E1 by an erosional unconformity, near the Guadalquivir Allocthonous front, and from the Unit D by the high-amplitude reflector $H 3$ in the rest of the area. 


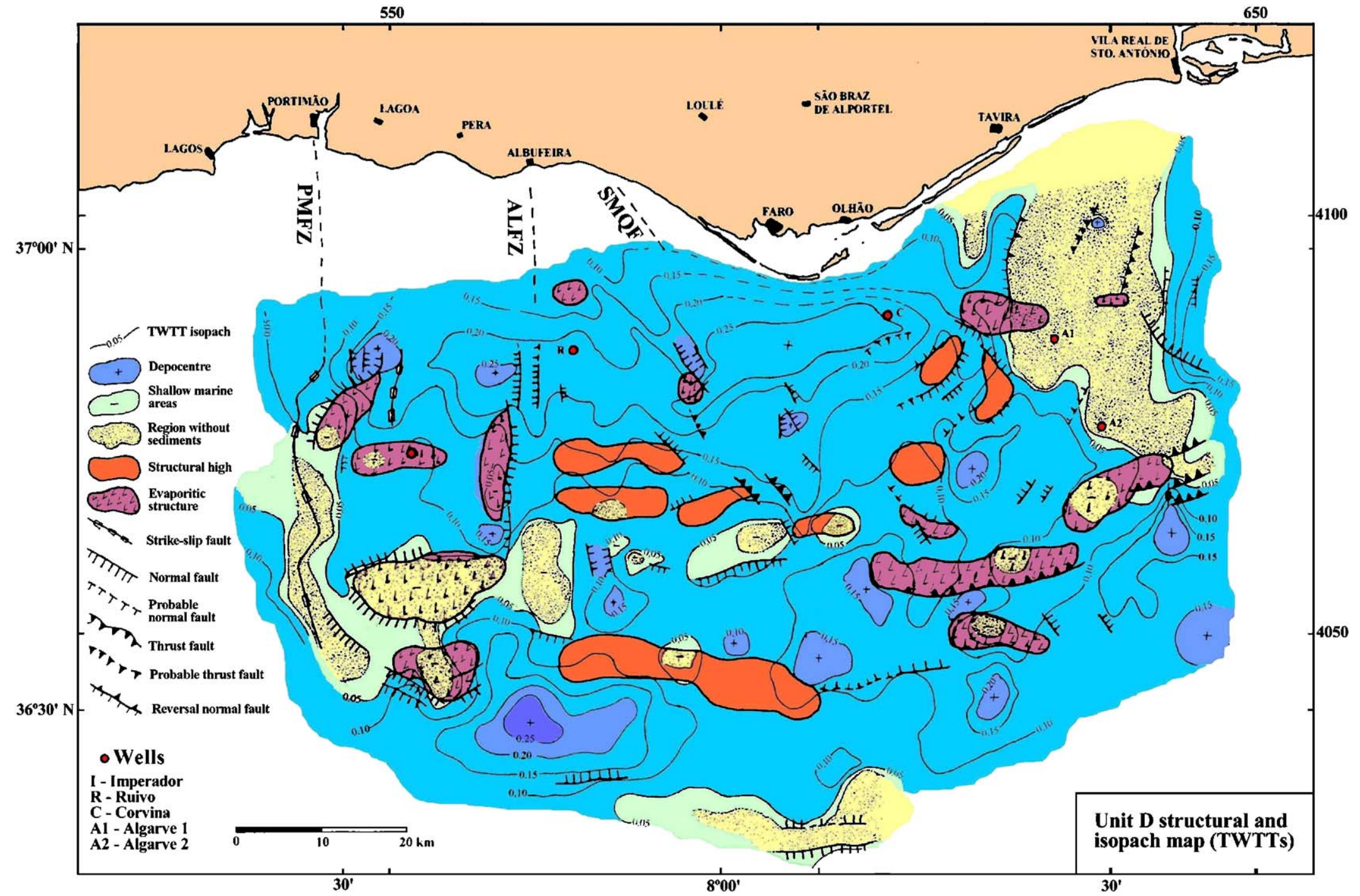

Fig. 8. Unit D structural and isopach map (TWTTs). PMFZ — Portimão-Monchique Fault Zone; ALFZ — Albufeira Fault Zone; SMQF — São Marcos-Quarteira Fault Zone; TF — thrust front; FB — foredeep basin; ITB — imbricated thrust belt. 
TWTT (s)

TWTT (s)

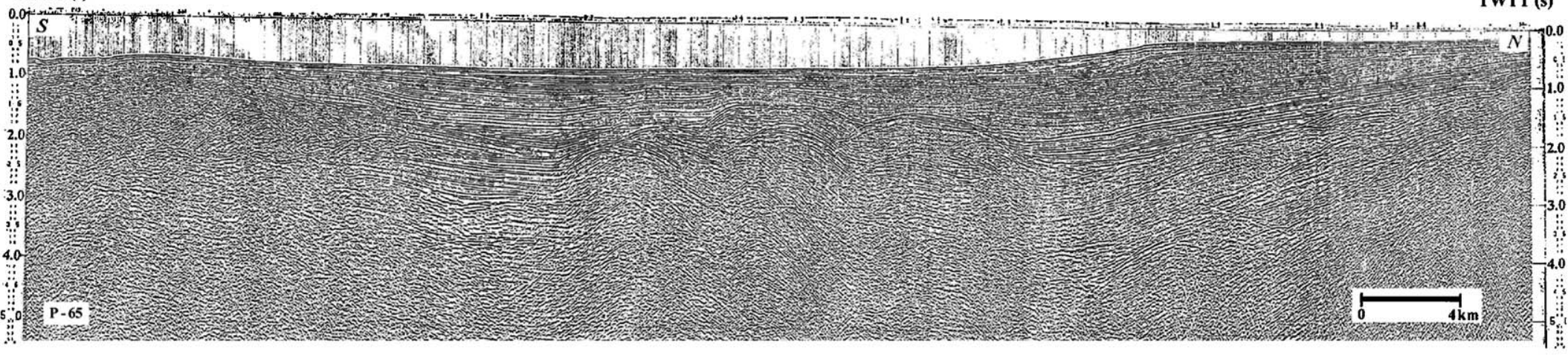

TWTT (s)

TWTT (s)

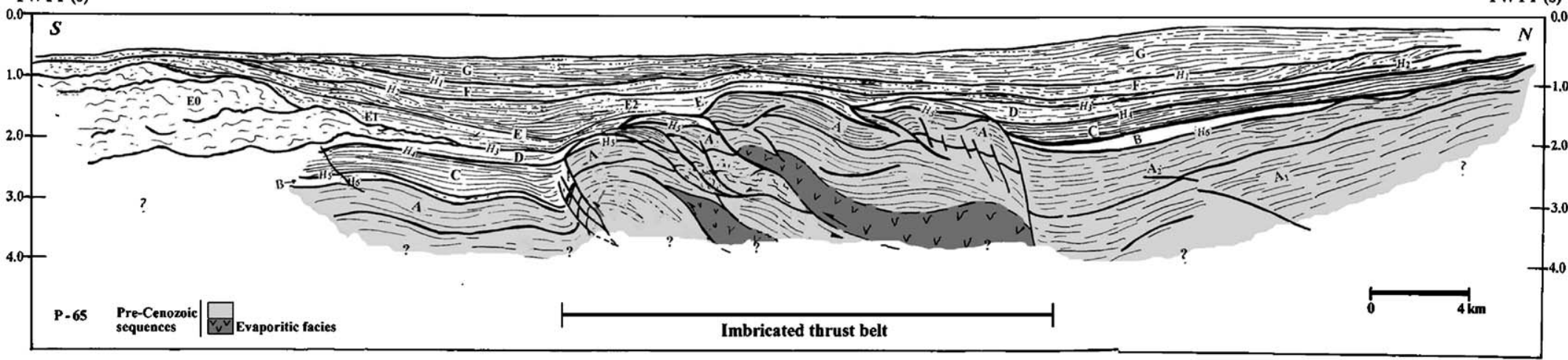

Fig. 9. P-65 seismic profile and corresponding interpretation (see Fig. 3 for location). TF — thrust front. The central section is dominated by a thin-thick skinned imbricated thrust belt. The south section is dominated by the Guadalquivir Allochthonous front. 


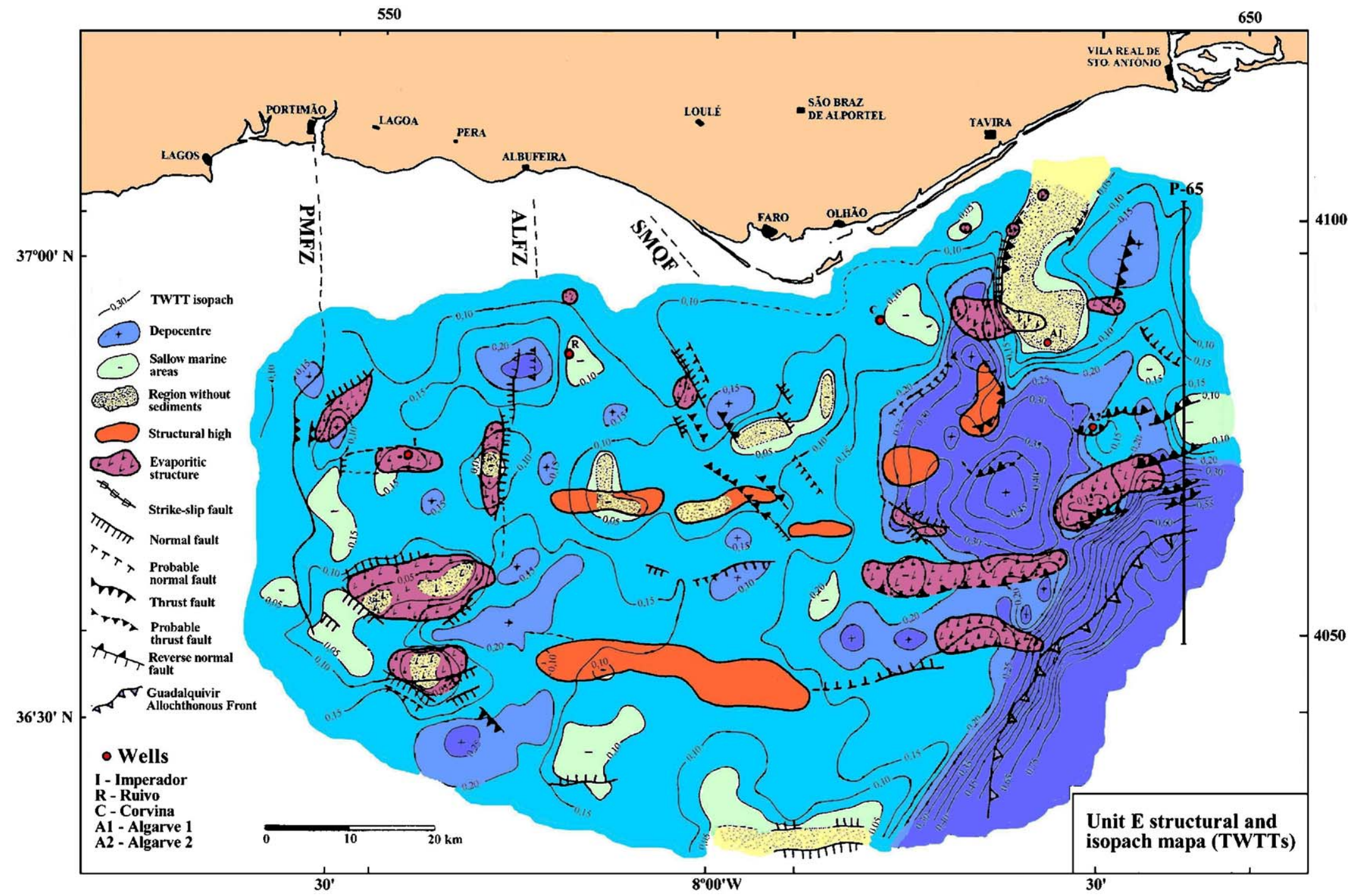

Fig. 10. Unit E structural and isopach map (TWTTs). PMFZ — Portimão-Monchique Fault Zone; ALFZ — Albufeira Fault Zone; SMQF — São Marcos-Quarteira Fault Zone; TF — thrust front; ITB - imbricated thrust belt. 
Landward, this subunit is characterised by low-amplitude and discontinuous reflectors with high frequency, showing southwards sigmoid progradational configuration, alternating with rather transparent zones. This seismic facies is consistent with the siliciclastic deposits documented for this unit by well data. Basinwards, the seismic facies displays subparallel and continuous reflectors of high amplitude and low frequency, showing a general divergent filling external configuration. Near the allocthonous front, subunit E2 exhibits a complex fill reflection pattern and also drapes the top of the Guadalquivir Allocthonous unit.

The deposition of subunit E2 indicates an increasing subsidence, mainly in the eastern part of the margin. The thickest deposits are observed in the flexural depocentres north of the allocthonous front, where they are $>0.55 \mathrm{~s}$ TWTT in thickness, whilst they thin markedly above the Guadalquivir Allocthonous unit (Fig. 9).

Subunit E2 could correspond to the Unit M3 described in the adjacent SW Spanish margin by Maldonado et al. (1999).

\subsection{Unit F (Zanclean)}

The lower boundary of Unit $\mathrm{F}$ is recorded by a continuous and moderate to high-amplitude reflector $(\mathrm{H} 2)$ that corresponds to a widespread erosional unconformity, assumed to be an uppermost Messinian feature.

The internal reflection pattern of Unit F consists of continuous, parallel and high-amplitude reflectors with low frequency. It grades upwards into a seismic facies made up of low-amplitude, discontinuous reflectors with high frequency. Chaotic reflectors occur locally, on the flanks and on the top of salt structures and in fault zones. In the northern area, the basal reflectors onlap landwards on top of the basal unconformity. From the well data (Imperador, Ruivo and Corvina), the lithologies indicate upper to lower bathyal mudstones and sandstones with interbedded sandy mudstones.

The thickness of Unit F is variable, as a function of the underlying fault-/salt structures (Fig. 11). Thicknesses $>0.6 \mathrm{~s}$ TWTT are documented in half-grabens, particularly in the western Algarve margin, where a divergent seismic reflection pattern is identified. This unit filled depressions. On the other hand, a rapid and generalised subsidence is documented south and southeastwards, forming a $\mathrm{N} 60^{\circ}$-trending axis parallel to an adjacent uplifted zone to the northwest that extends southwestwards from the Corvina well site and where Unit $\mathrm{F}$ is not identified (Fig. 11). Unit $\mathrm{F}$ is absent elsewhere in the narrow $35-\mathrm{km}$ long $\mathrm{N}-\mathrm{S}$ trending zone at the western end of the study area.
During time-period recorded in Unit F the halokinesis process decreased and salt diapirism was more located and piercing, forming small rim synclines.

It is suggested that Unit F correlates onshore with the Galvana Conglomerate (Pais et al., 2000), deposited in an alluvial environment and considered as Upper Messinian to lowermost Zanclean in age. Unit $\mathrm{F}$ also could correspond to the Unit P1 described in the SW Spanish margin by Maldonado et al. (1999) and to the Unit S3 described in the Alentejo basin (Alves et al., 2003).

\subsection{Unit G (Piacenzian to Holocene)}

The lower boundary of Unit $\mathrm{G}$ is a continuous, highamplitude reflector $(\mathrm{Hl})$ that corresponds to the erosional unconformity found over most of the Algarve margin, and which underlies the base of contourite deposits on the continental slope.

Unit $\mathrm{G}$ is a widespread sequence located between the Unit F and the sea bed (e.g. Figs. 6 and 9). It exhibits variable seismic facies both upwards in the stratigraphic sequence and laterally across the study area. In the northern area, mainly at the northern border of the Albufeira and Álvares Cabral deeps, seismic facies are characterised by discontinuous and very low-amplitude high-frequency reflectors, with a complex sigmoid-oblique progradational configuration southwards (Fig. 6). Towards the basin, seismic facies are characterised by continuous, subparallel and high-amplitude reflectors of low frequency, with aggradational and divergent configuration patterns; a migrating wave configuration also occurs. Chaotic reflectors occur on the flanks and on the top of salt structures, in fault zones and in the Portimão Canyon and Álvares Cabral Deep. According to well stratigraphy, Unit $\mathrm{G}$ is made up of turbiditic and current-drift sandstones.

A detailed seismic stratigraphy of Unit $G$ allowed Kreiter (1999) to identify three subunits that record different evolutionary stages of the margin: $i$ ) a lower subunit G1, coeval with the formation of the Portimão and Albufeira canyons and the Diogo Cão Deep; ii) an intermediate subunit G2, correlated with the establishment of the present-day Gulf of Cadiz current regime (shallow Atlantic inflow water; deep Mediterranean outflow water) (Vanney and Mougenot, 1981; Mougenot and Vanney, 1982, Stow et al., 1986; Nelson et al., 1993, 1999; Kreiter, 1999) and the beginning of the contourite drifts of Albufeira and Faro; iii) an upper subunit G3, during which deposition of the north-northwestwards progradational contourite drifts of Albufeira and Faro reached their present-day position.

Towards the basin, the deposition of subunits G1 and G2 recorded an important subsidence $(>0.7 \mathrm{~s}$ TWTT 
thickness) along a roughly $\mathrm{N} 60^{\circ}$-trending axis (Fig. 12). Thicknesses of more than $0.4 \mathrm{~s}$ TWTT are preserved in the contourite drifts. Just before the deposition of subunit G3, most of the underlying structures became inactive and the depressions were progressively filled.

Comparing offshore and onshore geology of the Algarve leads to a correlation of: 1) subunit G1 with the Olhos de Água Sands, dated as Piacenzian (Antunes et al., 1997; Pais et al., 2000); 2) subunit G2 with the Morgadinho and Algoz Deposits, dated as Lower Pleistocene (Antunes et al., 1986); and 3) subunit G3 with the Faro-Quarteira Formation, dated as uppermost Pleistocene (Chester and James, 1995) to Holocene (Antunes and Pais, 1992; Antunes et al., 1997; Moura and Boski, 1999; Pais et al., 2000). Comparisons with the adjacent SW Spanish margin further suggest the correlation of subunits G1, G2 and G3 with the Units P1, P2 and $\mathrm{P} / \mathrm{Q}$, respectively, described by Maldonado et al. (1999).

The H1 reflector probably corresponds to the lowermost Piacenzian/uppermost Zanclean unconformity identified by Cunha (1992a,b) and Alves et al. (2003) in other Portuguese Tertiary basins.

\section{Cenozoic tectonics}

The interpretation of the MCS data and the isopach maps deduced from correlating seismic lines, supply firstorder constraints for a multi-staged tectonic model for the Cenozoic evolution of the Algarve margin. Emphasis is put on: $i$ ) the main regional structures (fault zones; Guadalquivir Allochthonous front); ii) salt tectonics; and iii) the overall tectonic zonation of the margin.

Although the basement and Mesozoic structures are poorly imaged below $\mathrm{H} 6$ reflector, the interpretation of deeply-rooted features (salt structures, faults and thrusts) is attempted in the following section. The transpressive tectonics documented onshore by inverted structures emplaced at the Jurassic-Cretaceous boundary (Terrinha, 1998a) are not clearly imaged on the offshore seismic profiles (equivalent to the base of the A2 subunit; Fig. 4).

On the other hand, the Triassic-Hettangian evaporites lying near the base of the Mesozoic sedimentary pile are assumed to have played a key role during the structuration of the basin, by localising both extensional and thrust detachments and generating both salt structures and saltwithdrawal sub-basins (Terrinha, 1998a,b; Lopes, 2002).

\subsection{Main tectonic domains}

The Cenozoic structural evolution of the central and eastern sectors of the Algarve offshore basin is controlled by major fault structures that determine three main tectonic domains, all bounded to the south by the $\mathrm{N} 70^{\circ}$ trending Guadalquivir Bank (Fig. 13).

From $\mathrm{W}$ to $\mathrm{E}$, this composite fault-controlled basinal area comprises: a) the Western Central Domain; b) the Eastern Central Domain; and c) the Eastern Domain.

The narrow (25 km wide) and N-S-trending Western Central Domain covers a nearly $1500 \mathrm{~km}^{2}$ area limited to the west by the $\mathrm{N}-\mathrm{S}$ striking Portimão-Monchique Fault Zone (PMFZ) and to the east by the $\mathrm{N}-\mathrm{S}$ trending Albufeira Fault Zone (ALFZ) which is an anastomosing fault zone.

The Eastern Central Domain is a triangle-shaped area $\left(1300 \mathrm{~km}^{2}\right)$ bounded to the west by the ALFZ and to the east by the $\mathrm{N} 140^{\circ}$-striking São Marcos-Quarteira Fault Zone (SMQF).

The Eastern Domain is an irregular depression $\left(1800 \mathrm{~km}^{2}\right)$ dominated by compressive structures that are more complex than in the adjoining domains.

\subsubsection{Main bounding structures}

\subsubsection{The Portimão Monchique Fault Zone} (PMFZ). The N-S PMFZ, also identified onshore, is about $70 \mathrm{~km}$ long offshore. It is clearly evidenced on the E-W seismic reflection profiles, whose westernmost ends intersect the fault (Figs. 14-16). Its recent activity is actually expressed by the Portimão submarine canyon. According to Terrinha $(1998 \mathrm{a}, \mathrm{b})$ and Terrinha et al. (1999), the PMFZ is a segment of an intermittent Late Hercynian right-lateral vertical fault that was reactivated as a main transfer fault during extension and tectonic inversion of the Algarve basin and as a right-lateral strike-slip fault during the Late Cretaceous rotation of Iberia.

During the deposition of Unit C, the PMFZ probably acted as a right-lateral strike-slip fault as suggested by its right-stepping trace located northwestward of the Imperador well (Fig. 7). It is likely to have operated as a (syn-Unit C) releasing bend, allowing evaporitic rise to form a N40 ${ }^{\circ}$ salt wall (Figs. 13-15). The same fault step trace later behaved as a restraining bend after the deposition of Unit E, when the PMFZ became a leftlateral strike-slip fault as a consequence of the NW-SE Middle Tortonian compressive event (Terrinha et al., 1999). This changing fault kinematic is suggested by the compressive deformation of the post-Unit $\mathrm{C}$ sediments that are cross-cut by the fault in this place (Fig. 15), as well as by the narrow and probably uplifted belt along this fault zone in which units D (Fig. 8) and F (Fig. 11) are not represented.

6.1.1.2. The Albufeira Fault Zone (ALFZ). The ALFZ is a $30-\mathrm{km}$ long $\mathrm{N}-\mathrm{S}$ structure displaying major 


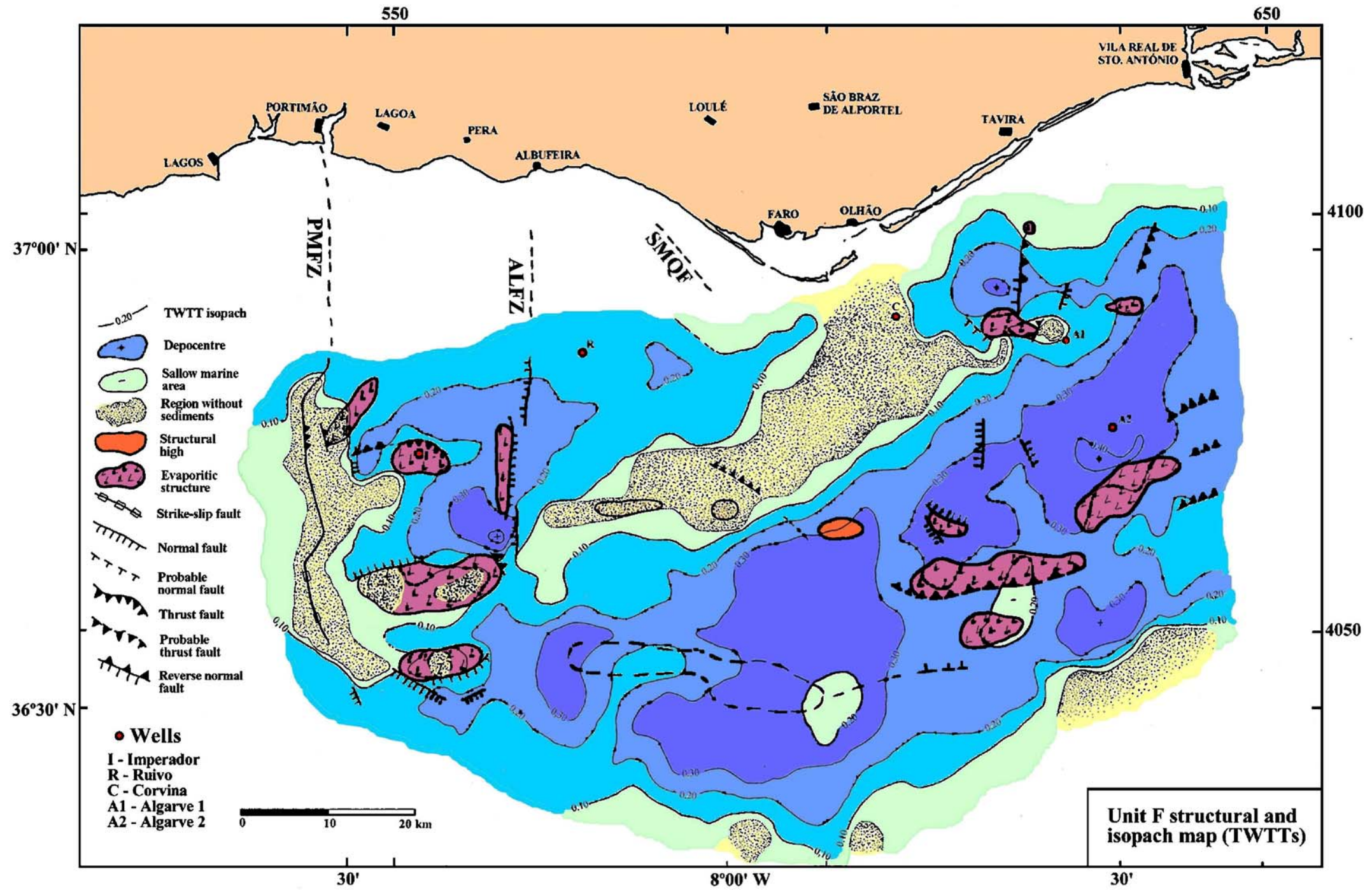

Fig. 11. Unit F structural and isopach map (TWTTs). PMFZ — Portimão-Monchique Fault Zone; ALFZ — Albufeira Fault Zone; SMQF — São Marcos-Quarteira Fault Zone; TF — thrust front; ITB - imbricated thrust belt. 


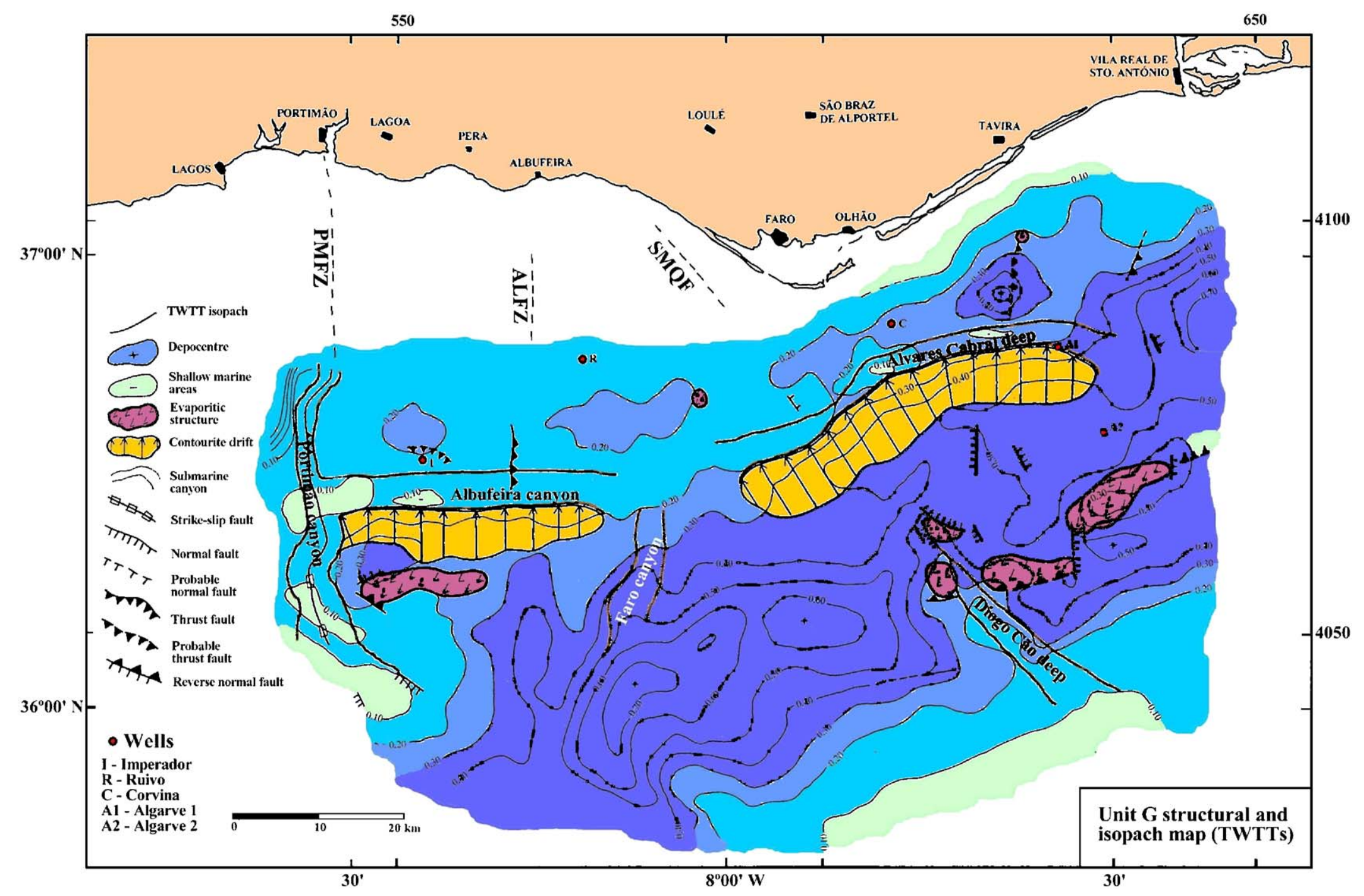

Fig. 12. Unit G structural and isopach map (TWTTs). PMFZ — Portimão-Monchique Fault Zone; ALFZ — Albufeira Fault Zone; SMQF — São Marcos-Quarteira Fault Zone; TF — thrust front; ITB - imbricated thrust belt. 


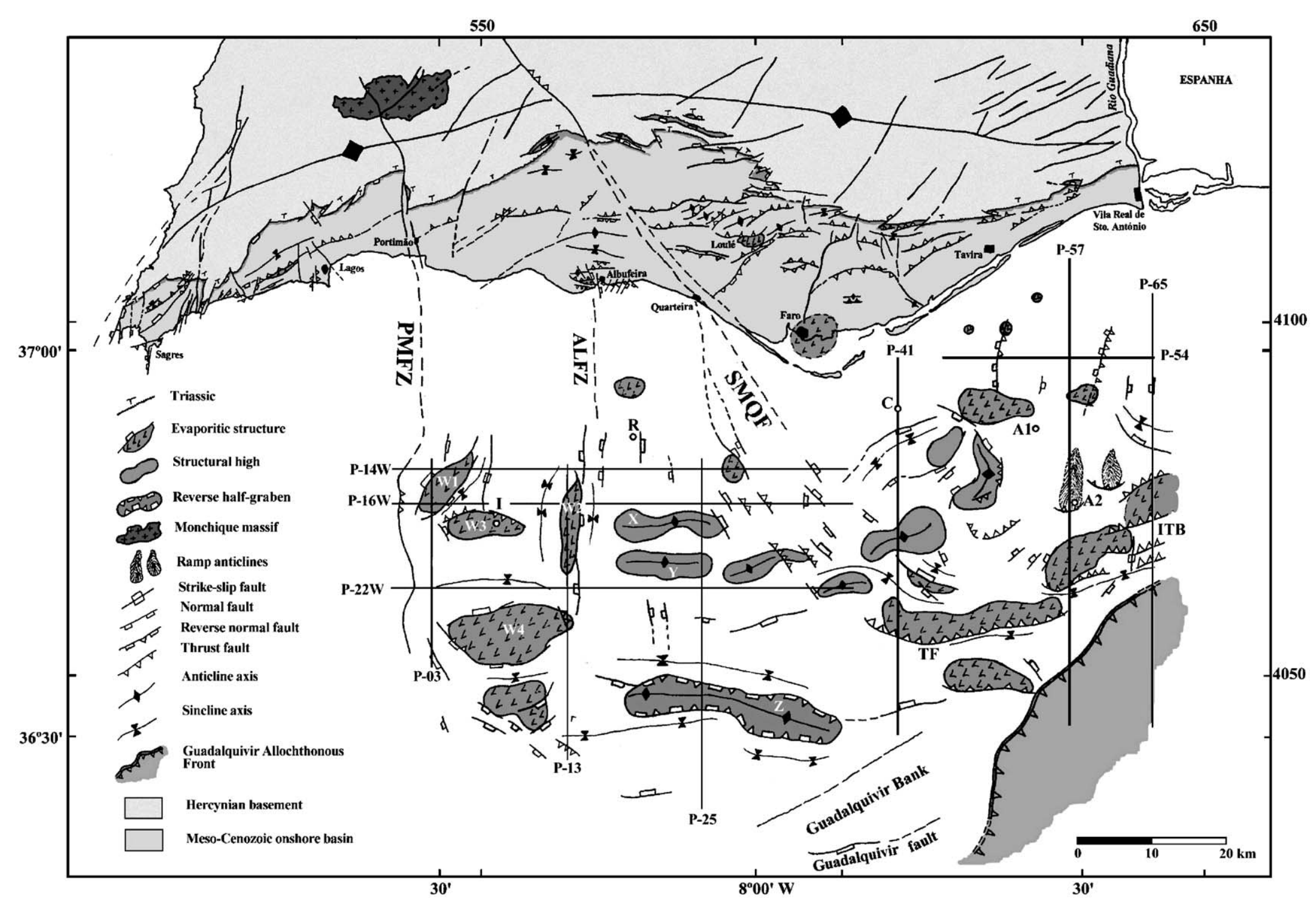

Fig. 13. Synthesis map of the main Cenozoic structures, integrating the onshore (Terrinha, 1998a) and the offshore (Lopes, 2002) areas. PMFZ — Portimão-Monchique Fault Zone; ALFZ — Albufeira Fault Zone; SMQF — São Marcos-Quarteira Fault Zone; TF — thrust front; ITB — imbricated thrust belt. Solid lines: the seismic profiles showed in this paper. 


\section{TWTT (s)}

TWTT (s)

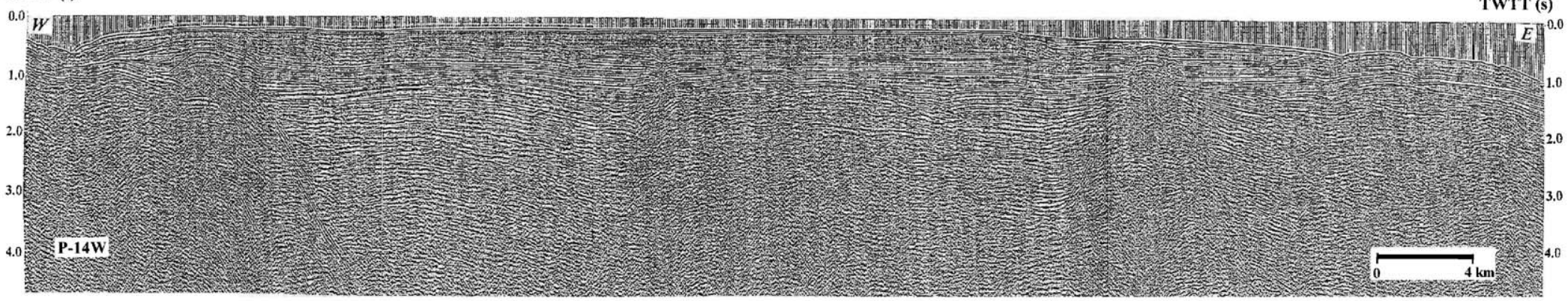

TWTT (s) Portimão

TWTT (s)

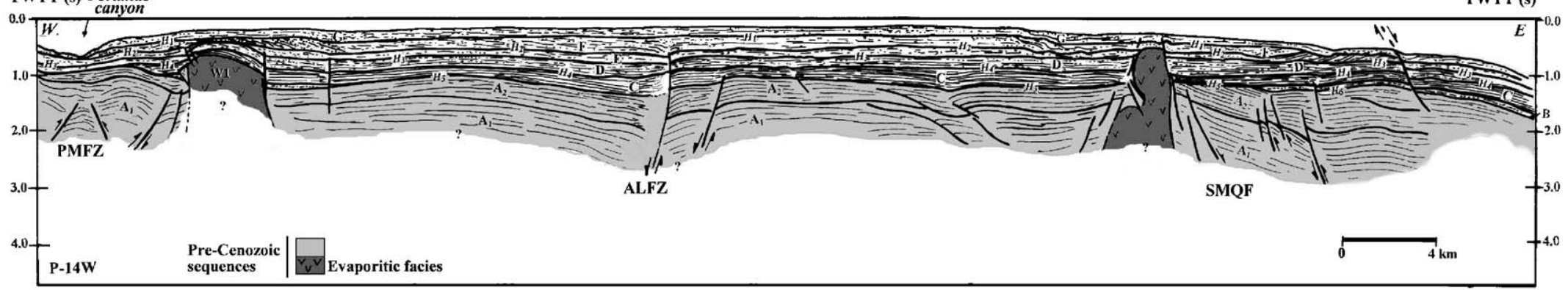

Fig. 14. P-14W seismic profile and corresponding interpretation (see Fig. 3 for location). PMFZ — Portimão-Monchique Fault Zone; ALFZ — Albufeira Fault Zone; SMQF — São MarcosQuarteira Fault Zone. Close to the ZFPM, an evaporitic structure trending $\mathrm{N} 40^{\circ} \mathrm{E}$ is located. 

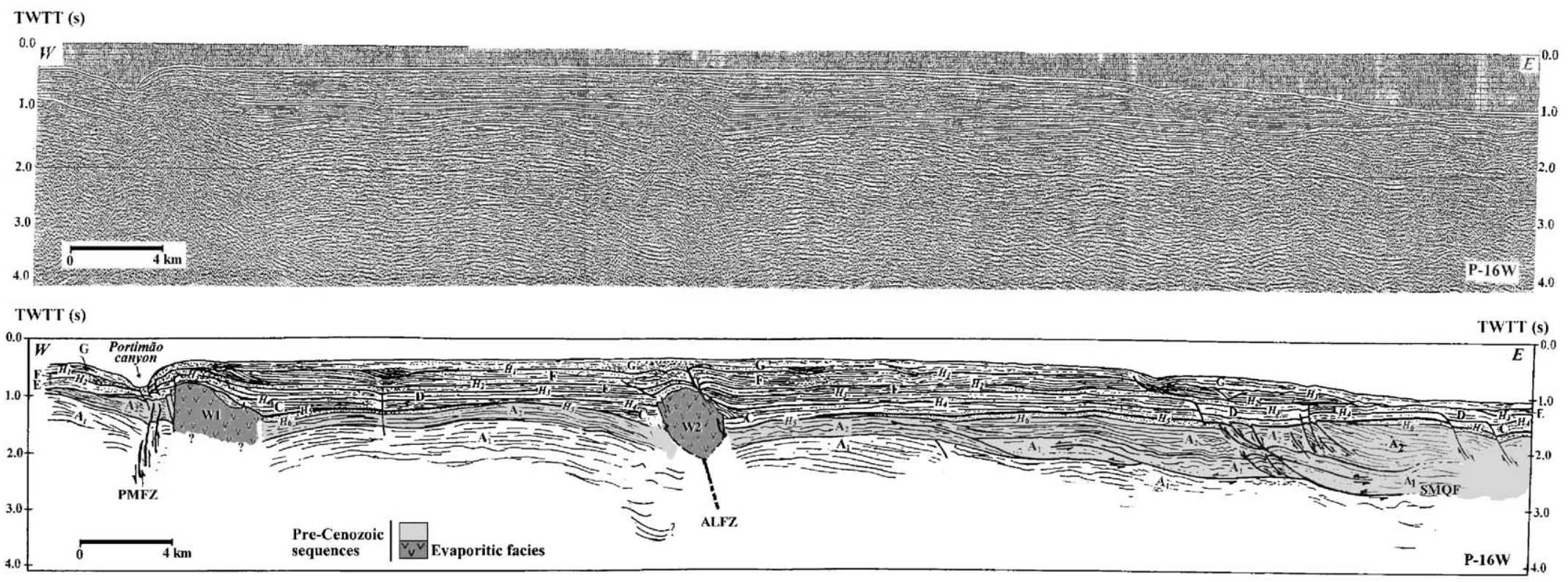

Fig. 15. P-16W seismic profile and corresponding interpretation (see Fig. 3 for location). PMFZ — Portimão-Monchique Fault Zone; ALFZ — Albufeira Fault Zone; SMQF — São MarcosQuarteira Fault Zone. During the deposition of the Unit D, halokinesis was relatively moderate as shown by the minor growth observed within Unit D on the flanks of salt structures. 


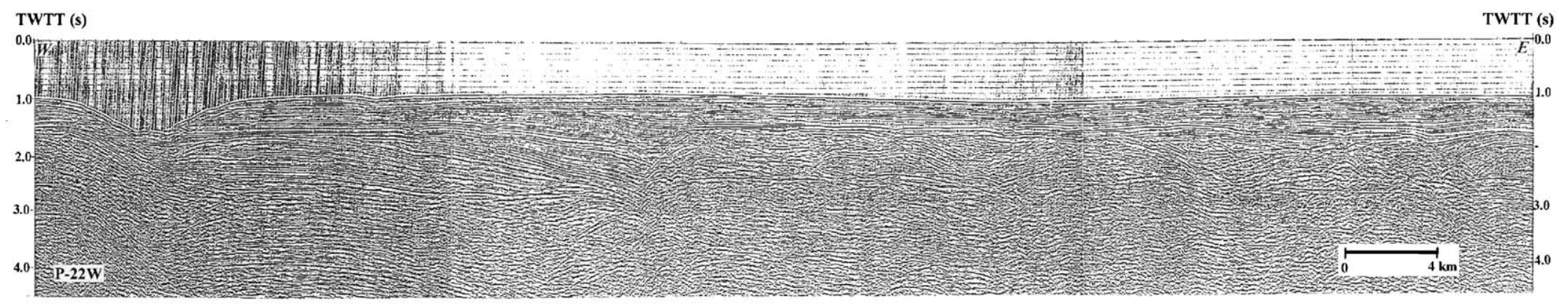

TWTT (s)
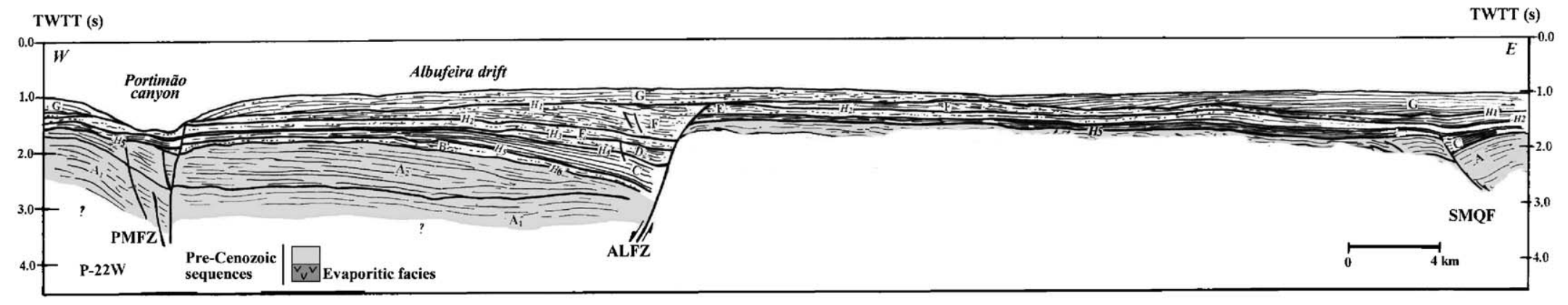

Fig. 16. P-22W seismic profile and corresponding interpretation (see Fig. 3 for location). PMFZ — Portimão-Monchique Fault Zone; ALFZ - Albufeira Fault Zone. The ALFZ as a westward dipping listric normal fault. 
variations in structural styles along-strike as depicted on seriated seismic lines cutting the fault zone at high angle (Figs. 14-16). These variations are described below, from north to south:

On profile P-14W (Fig. 14), the ALFZ is a steep westerly-dipping extensional fault. From the wedgeshaped geometry of the sedimentary packages in its hanging-wall, major Cenozoic fault displacement is likely to have occurred during deposition of Unit $\mathrm{C}$ (Lutetian to Oligocene). The ALFZ is sealed by Unit G (Piacenzian to Holocene);

On profile P-16W (Fig. 15), about $4 \mathrm{~km}$ further south of $\mathrm{P}-14 \mathrm{~W}$, the ALFZ lies as an easterly-dipping fault structure that crosscuts a salt tongue. The nature of the fault zone is not clear, but evidence for motion up to Unit $G$ are documented in relation to salt emplacement;

On profile P-22W (Fig. 16), about $12 \mathrm{~km}$ to the south of P-16W, the ALFZ shows a westerly-facing geometry as observed on section P-14W. Evidence for important extensional displacements are found along the eastern margin of an easterly-facing half-graben filled with syn-tectonic sequences ranging from Unit $\mathrm{C}$ up to Unit F (Fig. 17). The southern part of the ALFZ is thus a long-lived normal fault structure that has been active during deposition of units $\mathrm{C}, \mathrm{D}$, and $\mathrm{F}$, with quiescence during the deposition of Unit $\mathrm{E}$, which has the same thickness on both sides of the fault. The fault displacement is sealed by Unit G.

The ALFZ appears as a segmented extensional fault structure involving three main fault segments with opposite polarities. It also shows along-strike diachronous activity with younger (syn-Unit F) fault displacement along its southernmost segment.

\subsubsection{The São Marcos-Quarteira Fault Zone} $(S M Q F)$. The SMQF is a $\mathrm{N} 140^{\circ}$-striking structure, about $70 \mathrm{~km}$ long, that coincides with the Diogo Cão Deep and continues northwestwards onshore (Fig. 13).

According to Terrinha (1998a,b), the SMQF is an inherited Hercynian thrust reactivated as a main dextral transtensional fault during Mesozoic extension. Downthrowing of the eastern block allowed deposition of a pile of sediments in the eastern area of the basin, more than twice as thick as in the west. During tectonic inversion, the SMQF was reactivated mainly as a dextral strike-slip fault.

The SMQF separates the Central Eastern Domain from the Eastern Domain; the later shows a different tectonic pattern. On profile P-14W, the SMQF is locally injected by a $2-\mathrm{km}$ thick vertical salt diapir (Fig. 14). On profile $\mathrm{P}-16 \mathrm{~W}$, the SMQF is a $10-\mathrm{km}$ wide fault zone expressed by a set of thrusts that pre-dates the $H 5$ unconformity and was later reactivated firstly as normal faults during the deposition of Unit $\mathrm{C}$ and then as reverse faults, syn- and post-Unit $\mathrm{E}$ but pre-Unit $\mathrm{F}$ (Fig. 15). The SMQF lies as a transfer fault connecting southwards into the southerly-verging E-W thrust front located in the Eastern Domain (Fig. 13).

\subsubsection{The Guadalquivir Bank. The Guadalquivir} Bank forms a $28-\mathrm{km}$ long and $12-\mathrm{km}$ wide N70 -trending morphotectonic high, outcropping on the seafloor at a depth of $550 \mathrm{~m}$ (Gulf of Cadiz gravimetric high B; Gràcia et al., 2003). Located on the middle continental slope of the southern Iberian margin, $100 \mathrm{~km}$ south of Faro, the Guadalquivir Bank is the offshore continuation of the Hercynian basement as evidenced from dredged rocks equivalent to the Volcano-Sedimentary Complex of the Pyrite Belt and the Beja-Arcena Metamorphic Belt (Vegas et al., 2004). Dañobeitia et al. (1999) suggested that this basement high was formed during the Triassic, in relation to the extensional (pre- and syn-rifting) phase that characterises the southern Iberian margin and the north African rift systems. An alternative explanation is considered by Vegas et al. (2004) who consider the

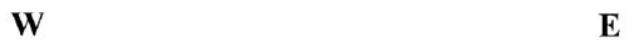

a)
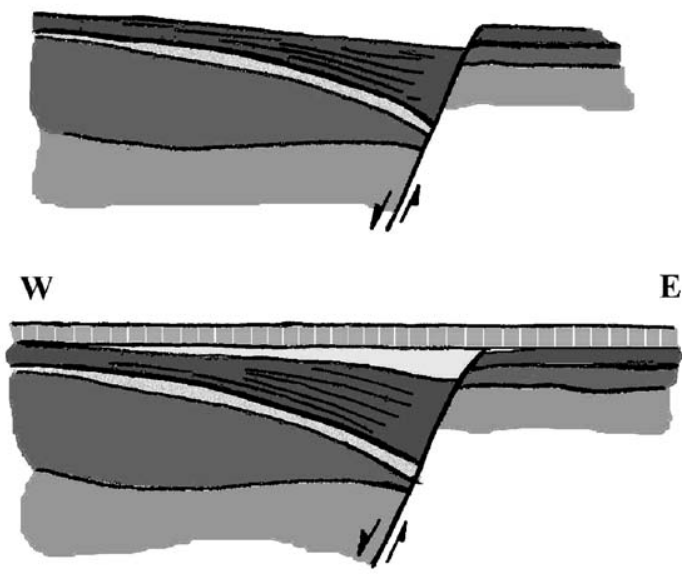

W

E

c)
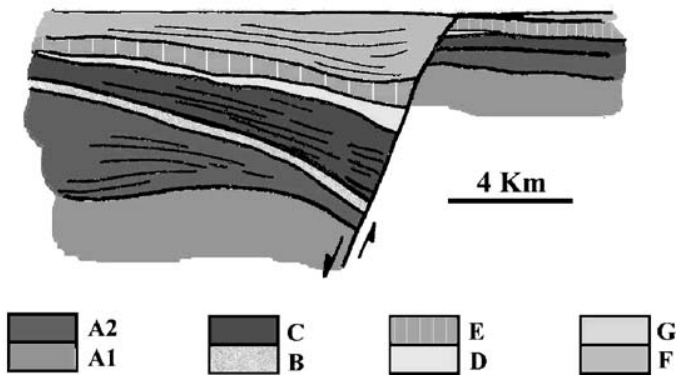

Fig. 17. Schematic reconstructed cross-sections (a to c) of the ALFZ listric normal fault coeval to the deposition of units $\mathrm{C}$ to $\mathrm{G}$. 


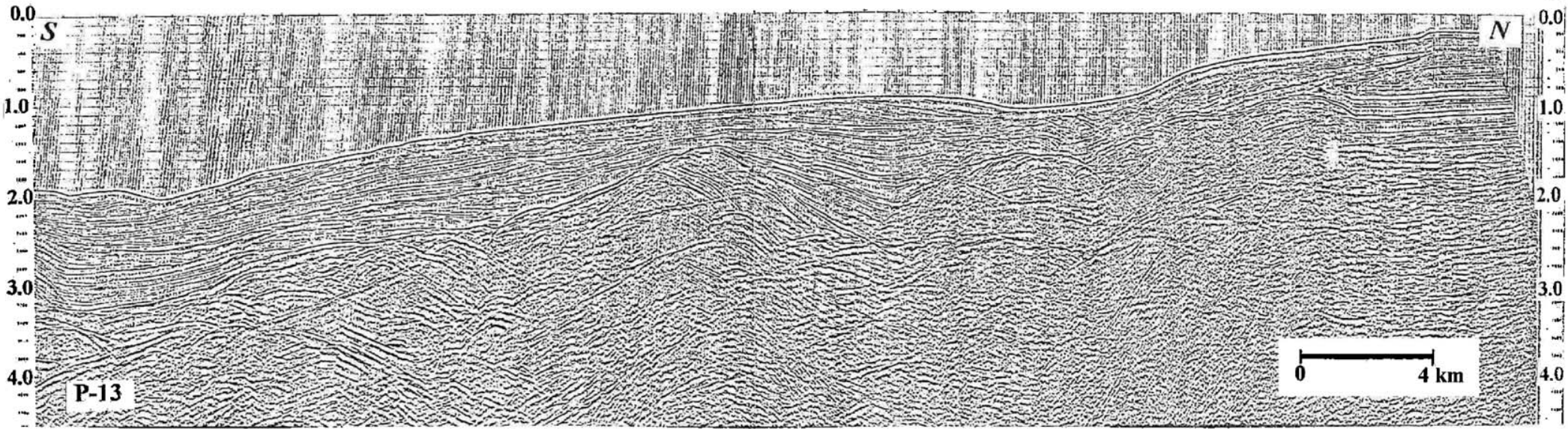

TWTT (s)

TWTT (s)

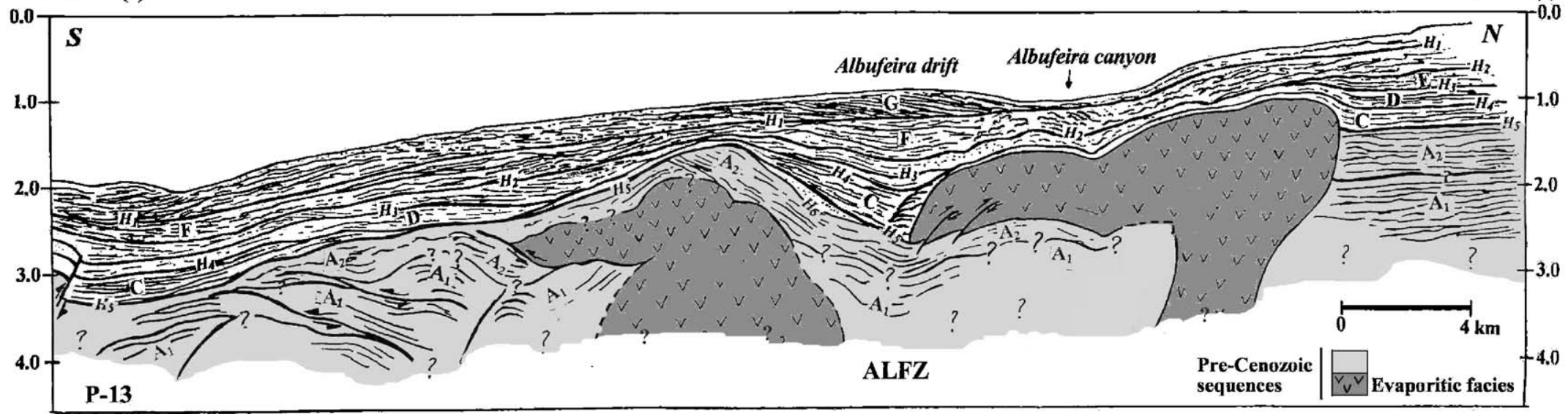

Fig. 18. P-13 seismic profile and corresponding interpretation (see Fig. 3 for location). Some evaporitic injection occurred along the ALFZ, with formation of an elongated N-S asymmetric salt wall, with an overhang tongue projected southwards. 
TWTT (s)

TWTT (s)

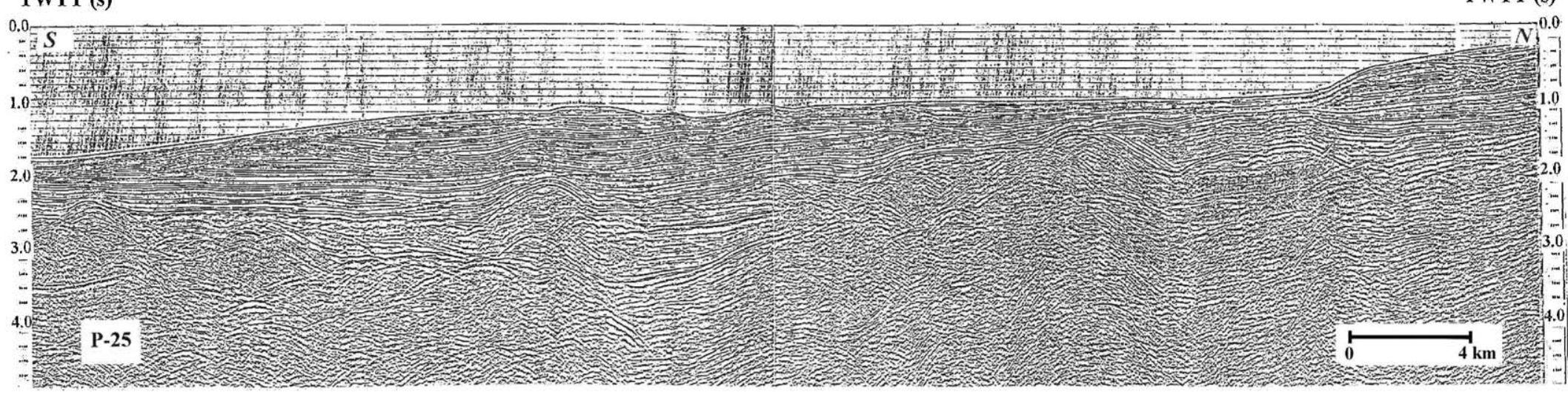

TWTT (s)

TWTT (s)

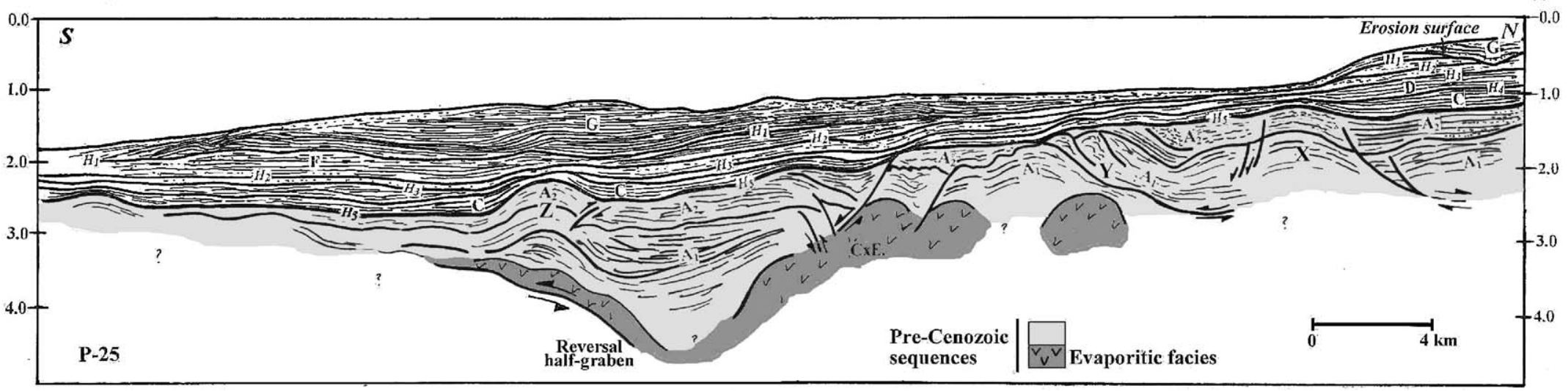

Fig. 19. P-25 seismic profile and corresponding interpretation (see Fig. 3 for location). The antiform located in the southern end of this profile (Z antiform) probably is an inverted Jurassic-Cretaceous halfgraben. 
Guadalquivir Bank as part of the high-standing marginal uplift that formed the southern boundary of the Mesozoic margin of Algarve, in a transform-fault context, instead of being part of a rift-type Mesozoic margin with a northsouth extensional direction.

The N-S seismic profiles cross-cutting the Guadalquivir Bank (P-35 to P-39; Lopes, 2002) indicate that both its northern and southern flanks are E-W to ENEWSW-trending extensional faults. The northern flank is bounded by a set of relatively small normal faults that were active mainly prior to Unit $\mathrm{C}$ deposition. The southern flank is bounded by a large south-dipping normal fault that increased its activity during the deposition of Unit $\mathrm{G}$, displacing the sea bed by several hundred meters. This structure corresponds to the Guadalquivir fault (Gràcia et al., 2003). Syn-sedimentary subsidence in the area south of the Guadalquivir Bank is suggested by the southerly thickening of Units F and $\mathrm{G}$. The corresponding extensional faults are difficult to interpret; they probably result from secondary extension associated with radial compressive stress around the Gibraltar Arc. The Guadalquivir Bank has been acting as a morphological barrier: i) during the Late Tortonian, to the advance of the Guadalquivir Allochthonous front; and ii) during present-day, to the Mediterranean Outflow Water (MOW) that flows along the Strait of Gibraltar.

\subsection{Structural style of each domain}

\subsubsection{Western Central Domain}

The Western Central Domain is a N-S trending area between the PMFZ and ALFZ meridional fault zones (Fig. 13).

The main morphotectonic features are controlled by four evaporitic structures: $i$ ) the structure labelled $\mathrm{W} 1$ is a $\mathrm{N} 40^{\circ}$ trending $10 \mathrm{~km}$ long evaporitic wall located in the eastern block of the PMFZ and associated with one of its bends; ii) the $\mathrm{W} 2$ structure is a narrow $\mathrm{N}-\mathrm{S}$ trending $12.5 \mathrm{~km}$ long evaporitic wall associated with the ALFZ central main fault segment (Figs. 13 and 18); iii) the W3 structure is an $\mathrm{E}-\mathrm{W}$ trending $10-\mathrm{km}$ long evaporitic wall located between the W1 and W2 structures; and $i v$ ) the W4 structure is an elliptic E-W trending (18-km long) evaporitic structure located in the southern side of the domain.

From the wedge-shaped geometry of the sedimentary packages in the salt-withdrawal sub-basins between the salt structures, major halokinesis activity is likely to have occurred during deposition of Unit C (Lutetian to Oligocene) and again from Unit E (Upper Tortonian to Messinian) up to Unit F (Zanclean). It shows a significant quiescence during deposition of Unit D (Aquitanian to Lower Tortonian) and attenuation during the deposition of Unit G (Piacenzian to Recent).

The southern flank of the W4 salt structure is bounded by conjugate normal faults. They have southwestern or southeastern steep dips and the sedimentary geometry in the tilted blocks suggests major displacements syn- and post-Unit $\mathrm{C}$ but pre-Unit $\mathrm{D}$, post-Unit F but pre-middle Unit G.

The N-S seismic profiles show that in the Western Central Domain, the $H 5$ reflector (the lower boundary of the Unit $\mathrm{C}$ ) is an important angular unconformity that truncates the folded units A and B (Fig. 6), suggesting an important post-Unit A, but pre-Unit $\mathrm{C}$, compressive event.

\subsubsection{Eastern Central Domain}

The Eastern Central Domain behaved as a dominantly elevated area during most of the evolution of the margin, with very few sedimentary depocentres and fault structures.

a)

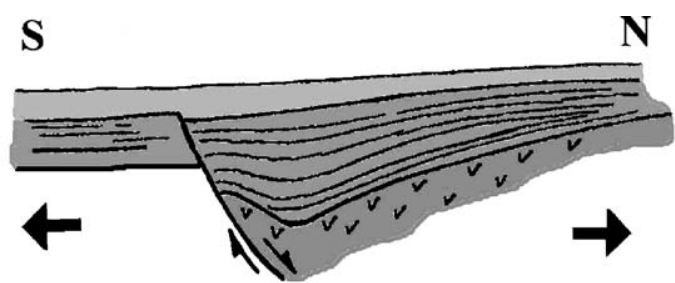

$\mathbf{S}$

b)

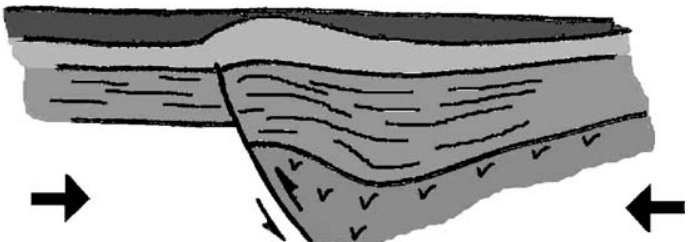

c)
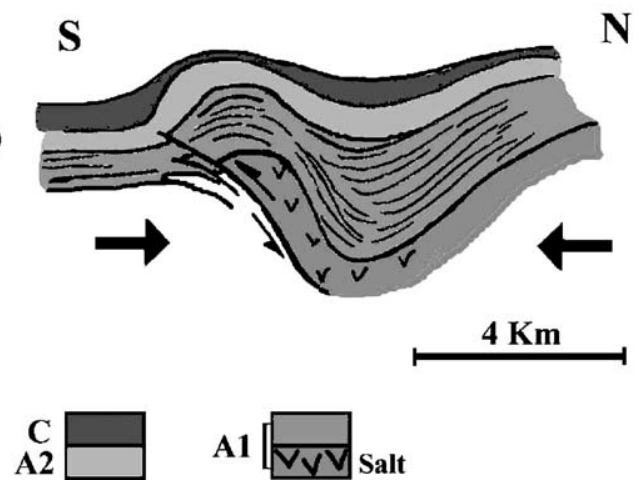

Fig. 20. Schematic reconstructed cross-sections of the $\mathrm{Z}$ antiform. a) from syn-subunit A1 to subunit A2; b) from syn-H5 to syn-Unit $C$; c) post-Unit C. 
TWTT (s)

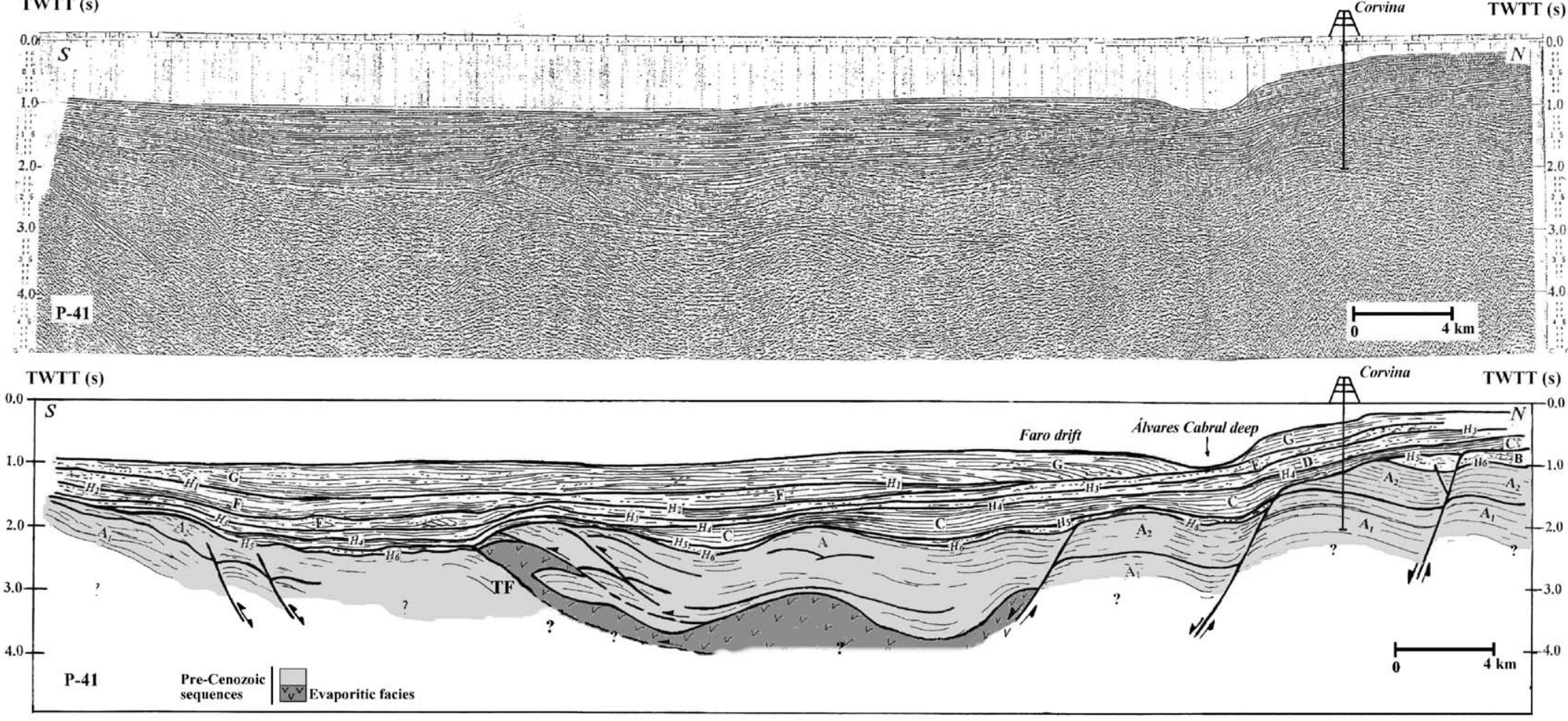

Fig. 21. P-41 seismic profile and corresponding interpretation (see Fig. 3 for location). TF - thrust front. 


\section{TWTT (s)}

Algarve 2

TWTT (s)
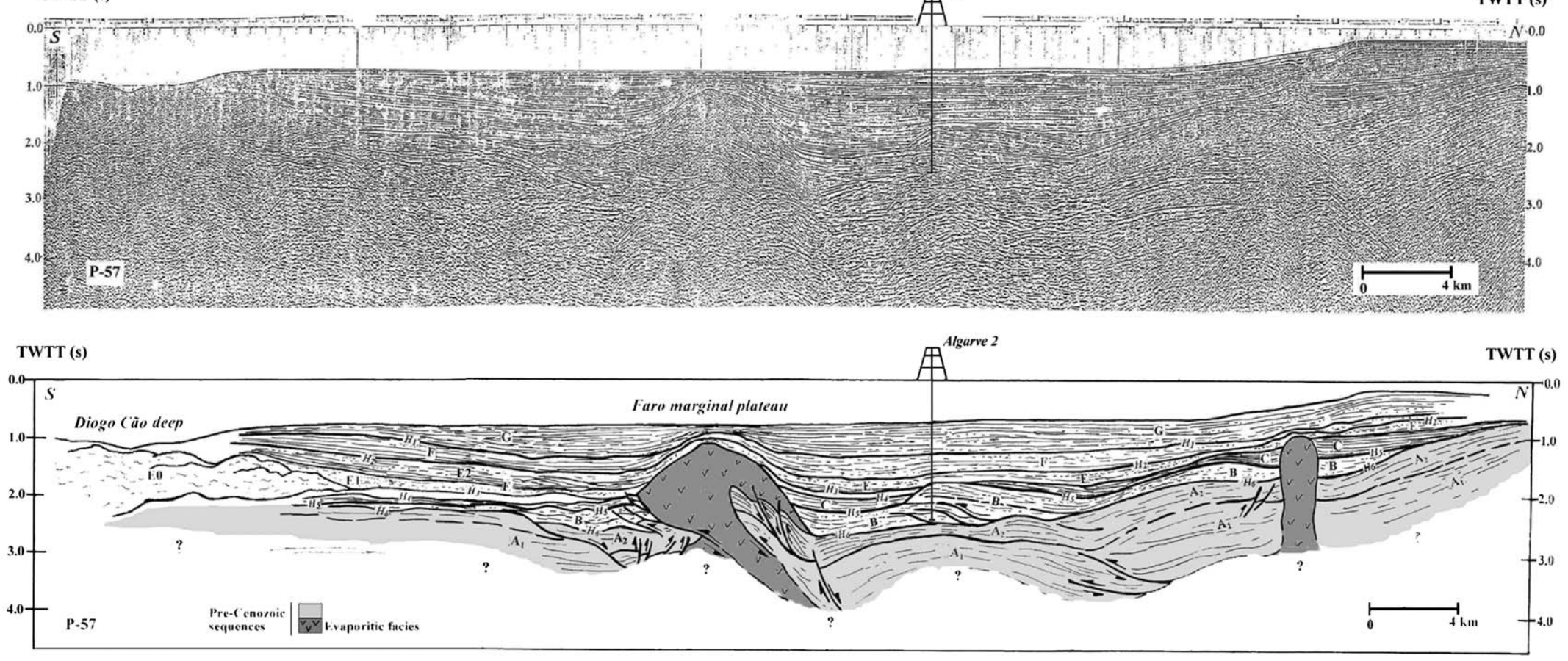

Fig. 22. P-57 seismic profile and corresponding interpretation (see Fig. 3 for location). 
TWTT (s)

TWTT (s)

$0.0 \mathrm{~W}+\mathrm{w}_{\mathrm{O}}$

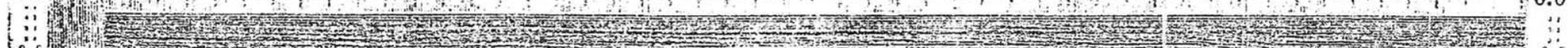

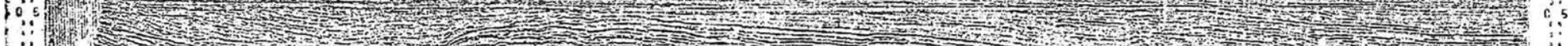

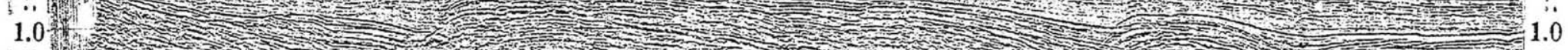

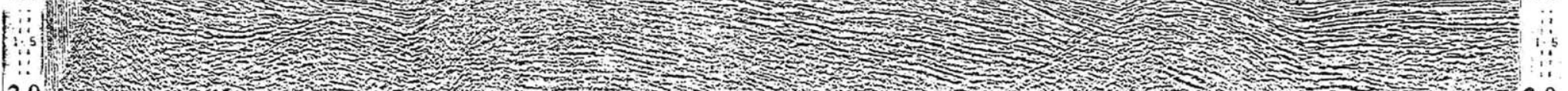
2.0.

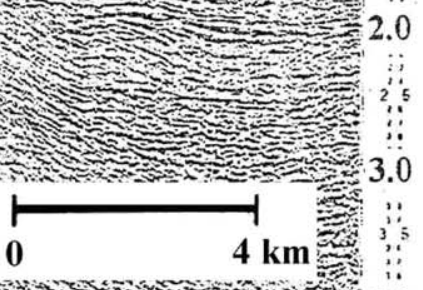

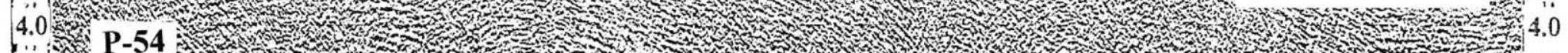

$1:$ : P-54

\section{TWTT (s)}

TWTT (s)

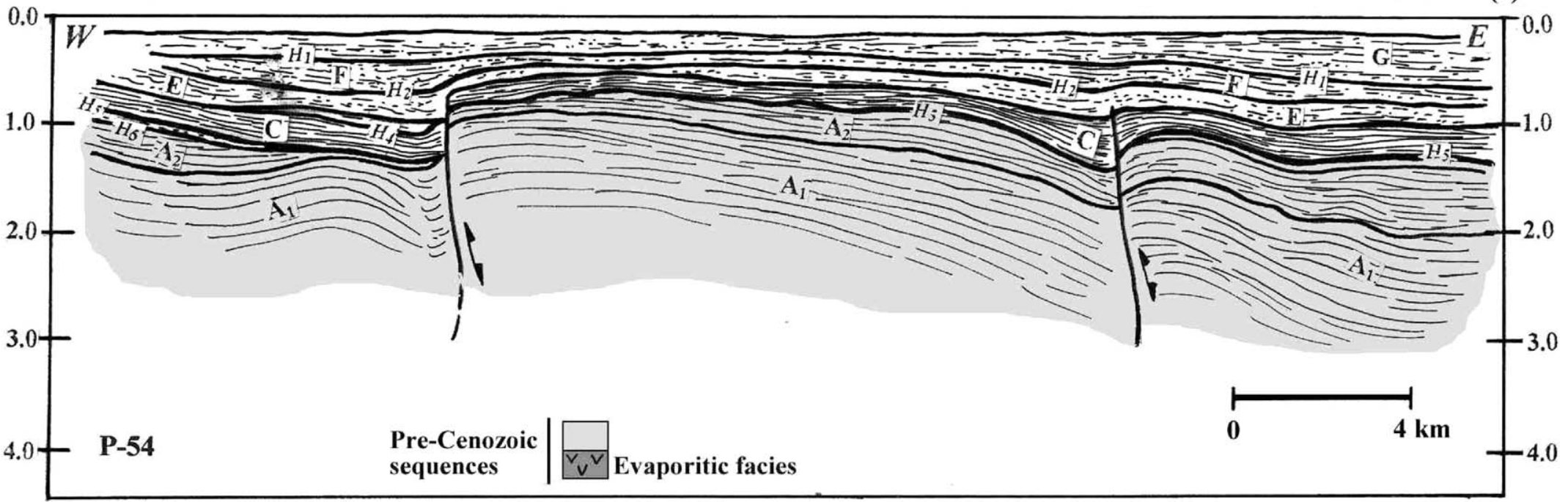

Fig. 23. P-54 seismic profile and corresponding interpretation (see Fig. 3 for location). This NNE-SSW thrust system results from the inversion of previous syn-Unit C distensive structures. 
The main morphotectonic features of this domain are three parallel antiformal axes striking E-W to ENEWSW (from north to south, labelled $X, Y$, and $Z$, respectively, on the tectonic map of Fig. 13), that were active during the deposition of units $\mathrm{D}$ and $\mathrm{E}$.

The $Z$ structure (the longest of these structures) is located immediately north of the Guadalquivir Bank (Fig. 19) and probably resulted from the tectonic inversion of a Mesozoic half-graben that occurred during the successive compressional events: $i$ ) pre- to syn- $H 5$; ii) syn-Unit D to syn-Unit E (Fig. 20). Towards the east, this structure passes laterally into normal faults bounding the northern flank of the Guadalquivir Bank, but with opposite polarity.

These antiforms separate three sub-basins: i) the northern one, north of the $X$ structure, is a sub-basin with flexural character (Fig. 19). It has been active mainly during deposition of Unit $C$; ii) the central and iii) southern sub-basins are located north and south, respectively, of the $Z$ structure and show an E-W to ENEWSW orientation. They have been active during the deposition of units D and E. At the western end of the central sub-basin, a NNW-SSE striking fault set defines a small graben; at the eastern end this sub-basin shows a normal ENE-WSW striking fault set. The $Z$ structure became inactive after the deposition of Unit $E$ and allowed the central and the southern sub-basins to become a single and very subsident sub-basin at $\mathrm{N} 60^{\circ}$.

In some $\mathrm{W}-\mathrm{E}$ seismic profiles (Figs. 14 and 15 ) it is possible to identify some reverse faults and thrusts at depth beneath the H5 unconformity, related to the Lutetian compressive event (Cunha, 1992a,b). Some of these thrusts seem to be in close connection with the SMQF, and were reactivated firstly as normal faults during the deposition of Unit $\mathrm{C}$ and then as reverse faults, syn- and post-Unit E but pre-Unit F (Fig. 15).

\subsubsection{Eastern Domain}

The Eastern Domain, where the sedimentary pile is detached from the basement over the Triassic-Hettangian evaporites, is the most intricate structural domain. Three main types of structures controlled its Cenozoic evolution:

a) $\mathrm{N} 60^{\circ}$ trending structures, paralleling the coastline are expressed by:

a.1) Listric normal faults (profile P-41; Fig. 21) dipping to the southeast and located close to the upper slope, limit nearly 5-km wavelength halfgrabens to the northwest. From the wedgeshaped geometry of their sedimentary packages major fault displacement is likely to have occurred during deposition of Unit C, with quiescence during the deposition of Unit $\mathrm{D}$ and being sealed by Unit E. The Álvares Cabral Deep was developed on this fault system;

a.2) A 20-km wide zone of south vergent imbricate thrust faults (Figs. 9, 22) is located in the southeastern end of the Eastern Domain. The profile P-65 (Fig. 9) shows the maximum vertical amplitude of the thrust wedges, which probably involve salt slices and the basement at depth and an overlying sedimentary pile ranging in age up to Unit E (Upper Tortonian to Messinian) (thin and thick-skinned thrusts). Significant changes in structural styles are observed laterally on profile P-57 (Fig. 22) along which the thrust wedge is associated with a salt diapir piercing upwards through the Cenozoic up to Unit G. On the northern side of the salt diapir, downslope, a thrust wedge involving units B, C, D and base of Unit E, was drilled by the Algarve-2 well.

b) A $20-\mathrm{km}$ long E-W to ENE-WSW trending thrust front, verging to the south, lies north of the Guadalquivir Bank, near the $36^{\circ} 38^{\prime}$ parallel. On profile P-41 (Fig. 21) this thrust front shows a thin and flat-lying salt body at depth, overlaid by an imbricate thrust wedge, directed to the south and involving Unit A slices. It might have acted as a blind fault, emplaced during deposition of units $\mathrm{C}$ and $\mathrm{E}$.

c) A NNE-SSW trending set of reverse faults, verging to the NW and located south-southeast of Tavira (Fig. 23), results in the positive inversion of previous distensive structures coeval to Unit C (Fig. 24).

As a synthesis, the Eastern Domain is dominated by a $40-\mathrm{km}$ wide $\mathrm{E}-\mathrm{W}$ to $\mathrm{N} 60^{\circ}$ trending zone of thrusting, verging to the south. A frontal tip zone to the south is

a)

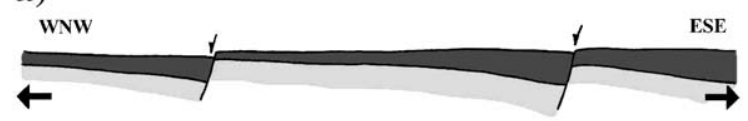

b)

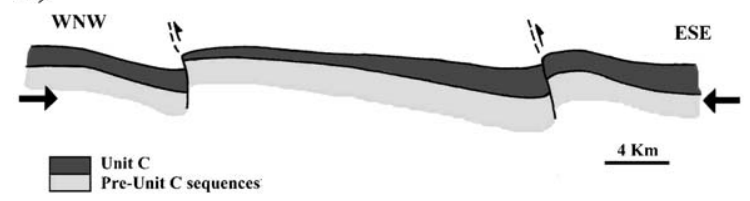

Fig. 24. Schematic reconstructed cross-sections of the NNE-SSW thrust system and the associated half-grabens. a) Syn-Unit C; b) from syn-Unit D to Unit E. 
clearly recorded and probably associated with syn-thrust sedimentary wedges. The main Cenozoic episode of reverse faulting is coeval to the generation of the Unit $\mathrm{E}$ lower boundary.

\section{Discussion}

\subsection{Cenozoic salt tectonics}

The overall structural evolution of the study area during the Cenozoic is dominated by a persistent halokinesis recorded since the Late Cretaceous, and triggered by the regional stress field that also rejuvenated deeply-rooted basement structures. Salt tectonics was favoured by the Triassic-Hettangian evaporites that acted as a detachment horizon under the thick $(>1-2 \mathrm{~km})$ overlying sedimentary cover. The evaporitic structures are mainly localized in the Western Central and Eastern domains, associated with predominant fault systems. Their activity was responsible for the location of the salt withdrawal depocentres, the development of the depositional/erosional events, and the probable modifications of the water flow distribution and related sedimentary processes.

The study area records relatively mild halokinesis from Late Campanian to Lutetian and from Aquitanian to Lower Tortonian, whereas important halokinetic processes occurred during the two following periods:

i) During Lutetian to Oligocene, a significant structural rearrangement occurred over the area studied, synchronous with halokinetic activity. In the Central Western Domain, the W1, W2, W3 and $\mathrm{W} 4$ evaporites intruded along $\mathrm{N} 40^{\circ}, \mathrm{N}-\mathrm{S}$ and $\mathrm{E}-\mathrm{W}$ alignments. Salt withdrawal from interdiapiric areas into these growing salt walls resulted in the formation of two main salt-withdrawal sub-basins with localised subsidence, and with a N-S trend on the flanks of the W2 salt wall (associated to the ALFZ central main fault segment; Fig. 15) and an $\mathrm{E}-\mathrm{W}$ axis between $\mathrm{W} 3$ and $\mathrm{W} 4 \mathrm{E}-\mathrm{W}$ salt walls (Fig. 18). The N-S salt-withdrawal sub-basins were filled by the wedge-shaped Unit $\mathrm{C}$ that thickens towards the salt wall. The other sub-basin records a greater thickness of Unit $\mathrm{C}$ in the central area away from the growing W3 and W4 structures. The tectonic style in the Eastern Domain seems to result from both gravity gliding above a salt detachment layer and the inversion of a basement graben. We propose that the gravity gliding of the sedimentary cover was associated with uplift and tilting of the northern sector of the margin, enhanced by tectonic inversion (analogue of the Tertiary basin inversion and tilt of the Southern North Sea; Conward and Stewart, 1995). Glide tectonics were responsible for the development of an area in extension upslope and a compressive area downslope (Fig. 21). The extensional area is characterised by thin-skinned tectonics marked by listric normal faults striking $\mathrm{N} 60^{\circ}$ and resulting in half-grabens. These faultbounded depocentres are filled by the wedgeshaped unit $\mathrm{C}$ that thickens towards the halfgrabens boundary faults. The contractional area is characterised by syn-sedimentary folds, showing anticlines and synclinal depocentres, passing southward into the thin-skinned E-W to ENE-WSW thrust front, with salt injection along the thrust plane, and associated frontal sub-basins. This type of folds and associated thrust front might have formed along salt pinch-out in agreement with previous studies elsewhere. These consider the prominant role played by the basinward salt pinchout in forming frontal contractional structures by increasing frictional resistance at the base of the sedimentary pile, thus preventing further basinward translation of the sediments (Letouzey et al., 1996).

ii) During the Middle Tortonian to Zanclean, a sudden, intense and widespread growth of the earlier evaporitic structures took place and led to the formation of a number of new evaporitic domes in the proximal shelf of both the Eastern Central and Eastern domains. During this period, salt structures started to pierce their country-rock cover, hence generating circular or elliptical rim synclines (Figs. 14 and 22).

During the Piacenzian to Holocene, halokinesis seems to decrease over the submerged part of the margin whilst some diapirs are still active onshore during the same period (e.g. Loulé diapir; Terrinha et al., 1990).

\subsection{Compressive tectonics}

The overall Cenozoic evolution of the Algarve margin is characterised by a composite style of thinned/thickened deformation in response to a moderate/high regional compressional stress field.

After a moderate phase of shortening during the Paleocene-?Ypresian, a more intense compressional strain provoked strong tectonic inversion, with uplift, folding, thrusting and generation of the important $\mathrm{H5}$ unconformity during the Lutetian (Figs. 6, 15). In the Eastern Central Domain, the E-W trending Mesozoic half-graben became progressively inverted and the $\mathrm{Z}$ antiform started to develop (Fig. 20). At this stage, prominent vertical block faulting resulted in partial 
emergence/erosion of footwall domains such as in the northern sector of the margin and the Guadalquivir Bank. Westward, this phase of intense instability is indicated by a very scarce or non-existence sedimentary record (Hayes et al., 1972) and by an important uplift and amplification of the Gorringe Bank antiformal structure (Le Gall et al., 1997).

During the Lutetian to Oligocene, moderate compressional reactivation of basement-related structures generated widespread halokinesis. The progressive basement graben inversion in the Eastern Domain, with uplift and tilting of the northern sector of the margin, led to southerly-directed gravity gliding of the sedimentary cover above a salt detachment layer. The fold and thrust front structures that were generated downslope were caused by coeval extension upslope. Southeastward, $\mathrm{N} 60^{\circ}$ trending imbricated thrust faults were induced by the basement contraction.

From the Aquitanian to Middle Tortonian, regional compression seems to have increased. In the Eastern Central Domain, E-W antiform/synform structures developed with two sub-basins occurring north and south of the $\mathrm{Z}$ antiform (Fig. 20). The northeastern sector of the Eastern Domain underwent major uplift and southward tilting, related to the inversion of the NNE-SSW striking fault set and associated halfgrabens (Fig. 24).

The Middle Tortonian (Betic) highly compressive event is recognised by: (1) an important unconformity in the Algarve margin, i.e. the $H 3$ reflector that correlates with the BFU unconformity in the SW Spanish margin, and (2) the arrival of the Guadalquivir Allochthonous front to the southeast area of the Algarve margin (Figs. 9, 10, and 22). Most of the subunit E1 deposits seem to have been developed when the allochthonous mass, reaching the Gulf of Cadiz, eroded the underlying deposits and formed a clastic basal unit. An intense halokinesis was triggered, resulting in the formation of salt domes and the reactivation of previous salt structures (Figs. 14, 22). East of the SMQF, most of the previous structures, involving both the thrust front and the imbricate thrust faults, suffered thick/thin-skinned tectonic reactivation as the horizontal compression caused the inversion of basementrooted structures and the dragging of post-salt overburden above Triassic-Hettangian evaporites. The syndepositional fold structures coeval with Unit $\mathrm{C}$ sequences were shortened. The northeastern sector suffered an important uplift and southward tilting, leading to southerly-verging gravitational sliding and the formation of ramp anticlines downslope. A rapidly subsiding central sub-basin started to develop with a $\mathrm{N} 60^{\circ}$-oriented axis before migrating northeastwards (Figs. 9 and 10). The area west of the
SMQF underwent regional uplift due to the development of the $\mathrm{E}-\mathrm{W}$ anticlines (Figs. 15, 19, 20). The active N60 depocentre that was formed during the Pliocene to Holocene might be the shallow expression of a lithosphere-scale flexural bending process that occurred in response to a probable NW-SE compression.

\section{Conclusions}

Six main Cenozoic seismic units are identified in the Algarve margin from seismic profile interpretation calibrated by borehole stratigraphy. These units document three first-order structural domains, bounded by regional transverse fault zones, and involving a complex stratigraphical pattern with major unconformities related to tectonic events that affected the southwestern border of Iberia.

In the study area, salt structures were controlled by the main lineamentary fault zones and preferentially took place in the Eastern and Central Western domains. Thin/thick-skinned thrust systems are concentrated in the Eastern Domain and generally exhibit southerly or southeasterly vergences. This tectonic signature has been attributed to: i) the proximity of the Betic orogen to the east; ii) the control by the SMQF, acting as a buttress fault that prevents the westward propagation of the Gibraltar Arc compression; iii) the proximity of the Guadalquivir Allochthonous front.

Halokinesis was persistent during the overall Cenozoic basinal evolution, but it was emphazised during deposition of Units C (Lutetian to Oligocene) and E (Upper Tortonian to Messinian), and followed by attenuation. A salt-/fault-controlled thin/thick-skinned subsidence influenced the thickness and the lateral distribution of the sediments. An increasing flexure-type bending of the margin is identified, with spatial and temporal variations of the subsidence. A strong and widespread subsidence occurred south and southeastwards, forming a $\mathrm{N} 60^{\circ}$ trending axis depocentre, probably caused by NW-SE to NNW-SSE compressive regime.

The coexistence of both distensive and compressive tectonics during the Cenozoic history of the Algarve margin (mainly prior to Late Miocene) could result from the following phenomena: i) the horizontal migration of evaporites and the gravity gliding of the post-salt cover in association with basin tilt during basement fault inversion, creating adjacent areas under extension or compression; ii) interaction between the roughly NNW-SSE Africa/ Iberia convergence, that would generate a secondary ENE-WSW traction and the westward migration of the Gibraltar Arc (mainly since the Early Miocene). This interaction might have provoked the radial orientation of 
regional stress over the external domains, i.e. the Algarve margin to the west.

\section{Acknowledgements}

This work is part of the research projects POCTI/CTA/ 38659/2001 and DESIRE, of the Fundação para a Ciência e a Tecnologia and co-founded by the FEDER. This study has also been financially supported by the Centro de Geociências da Universidade de Coimbra, Centro de Geofísica da Universidade de Coimbra and the Centro de Geofísica da Universidade de Lisboa. The authors wish to thank the Portuguese Núcleo para a Pesquisa e Prospecção de Petróleo for the permission to use seismic profiles and well data. We are grateful to M. L. Mendes Victor and M. R. Portugal Ferreira for reviewing an early version of the manuscript; David Piper (Editor in Chief), Francisco Lobo (CSIC), Andrew Murray (Århus University) and an anonymous reviewer made helpful comments and suggestions at a later stage.

\section{References}

Algarve-1, 1982. Final well report. Arquivo Gabinete para a Prospecção e Exploração de Petróleo, n 21967-off/Exxon Esso, Prospecção e Produção, S.A.R.L.

Algarve-2, 1982. Final well report. Arquivo Gabinete para a Prospecção e Exploração de Petróleo, no 21973-off/Exxon Esso, Prospecção e Produção, S.A.R.L.

Alves, T.M., Gawthorpe, R.L., Hunt, D.W., Monteiro, J.H., 2003. Cenozoic tectono-sedimentary evolution of the western Iberian margin. Mar. Geol. 195, 75-108.

Antunes, M.T., Pais, J., 1992. Excursion C (Portuguese part): the Neogene and Quaternary of Algarve. Atlantic General Events During Neogene, I Cong. RCANS. Ciências da Terra (U. N. L.), vol. 11, pp. 57-66.

Antunes, M.T., Bizon, G., Nascimento, A., Pais, J., 1981. Nouvelles données sur la datation des dépôts miocènes de l'Algarve (Portugal). Ciênc. Terra (U. N. L.) 6, 153-168.

Antunes, M.T., Pais, J., Macedo, C.R., Portugal Ferreira, M., 1984. Datação K-Ar de Glauconites do Miocénico Superior de Galvanas e Campina de Faro (Algarve Oriental). Mem. Not., Publ. Mus. Lab. Mineral. Geol. Univ. Coimbra 98, 2-7.

Antunes, M.T., Mein, P., Nascimento, A., Pais, J., 1986. Le gisement pleistocène de Morgadinho, en Algarve. Ciênc. Terra (U. N. L.) 8, 9-22.

Antunes, M.T., Elderfield, H., Legoinha, P., Pais, J., 1997. The Neogene of Algarve. Field trip guide - Excursão 2 (Portuguese part). In: Gonzáles Delgado, A., Sierro, F.J., Pais, J. (Eds.), Coords., Second Congress R.C.A.N.S., Salamanca (Spain), Outubro de 1997, pp. 37-55.

Baptista, M.A., Lopes, C., Lopes, F.C., Miranda, J.M., 2000. Análise do sismo e do tsunami de 1722.12.27 (Tavira-Portugal). Abstracts of $2^{\mathrm{a}}$ Assembleia Luso-Espanhola de Geodesia e Geofísica, Lagos (Algarve, Portugal), 8-12 Fev. 2000, pp. 153-154.

Berástegui, X., Banks, C., Puig, C., Tabern, C., Walthan, D., Fernández, M., 1998. Lateral diapiric emplacement of Triassic evaporates at the southern margin of the Guadalquivir Basin,
Spain. In: Mascle, A., et al. (Ed.), Cenozoic Foreland Basins of Western Europe. Geol. Soc. Spec. Publ., vol. 134, pp. 49-68.

Berthou, P., Lereveld, H., 1990. Stratigraphic implications of palynological studies on Berriasian to Albian deposits from western and southern Portugal. Rev. Palaeobot. Palynol. 66, 313-344.

Bonnin, J., Olivet, J.L., Auzend, J.M., 1975. Structure en nappe à l'Ouest de Gibraltar. C. R. Acad. Sci., Paris 280, 559-562.

Buforn, E., Udías, A., Colombás, M.A., 1988. Seismicity, source mechanisms and tectonics of the Azores-Gibraltar plate boundary. Tectonophysics 152, 89-118.

Buforn, E., Sanz de Galdeano, C., Udías, A., 1995. Seismotectonics of the Ibero-Maghrebian region. Tectonophysics 248, 247-261.

Cachão, M., 1995. Utilização de nanofósseis calcários em biostratigrafia, paleoceanografia e paleoecologia. Aplicações ao Neogénico do Algarve (Portugal) e do Mediterrâneo Ocidental (ODP 653) e à problemática do Coccolithus pelagicus. $\mathrm{PhD}$ thesis, Universidade de Lisboa, 356 pp.

Casado, C., Sanz de Galdeano, C., Palácios, S., Romero, J., 2001. The structure of the Alboran Sea: an interpretation from seismological and geological data. Tectonophysics 338, 79-95.

Chester, D.K., James, P.A., 1995. The Pleistocene Faro/Quarteira Formation of the Algarve region, southern Portugal. Geomorphology $12,133-149$.

Conward, M., Stewart, S., 1995. Salt-influenced structures in the Mesozoic-Tertiary cover of the southern North Sea, U.K. In: Jackson, M.P.A., Roberts, D.G., Snelson, S. (Eds.), Salt Tectonics: A Global Perspective. AAPG Memoir, vol. 65, pp. 229-250.

Correia, F., 1989. Estudo Bistratigráfico e microfácies do Cretácico carbonatado da Bacia Sedimentar Meridional Portuguesa (Algarve). Dissertação de Doutoramento, Faculdade de Ciências de Lisboa, $400 \mathrm{p}$.

Corvina-1, 1976. Final Well Report. Arquivo Gabinete para a Prospecção e Exploração de Petróleo, n ${ }^{\circ}$ 21301- off/Challenger, Challenger Portugal Inc.

Cunha, P. Proença, 1992a. Estratigrafia e sedimentologia dos depósitos do Cretácico Superior e Terciário de Portugal Central, a leste de Coimbra. PhD thesis, Universidade de Coimbra, 262 pp.

Cunha, P. Proença, 1992b. Establishment of unconformity-bounded sequences in the Cenozoic record of the western Iberian margin and synthesis of the tectonic and sedimentary evolution in central Portugal during Neogene. First Congress R.C.A.N.S. - Atlantic General Events During Neogene (Abstracts), Lisboa, pp. 33-35.

Cunha, P. Proença, Pena dos Reis, R., 1995. Cretaceous sedimentary and tectonic evolution of the northern sector of the Lusitanian Basin. Cretac. Res. 16, 155-170.

Dañobeitia, J.J., Bartolomé, R., Checa, A., Maldonado, A., Slootweg, A.P., 1999. An interpretation of a prominent magnetic anomaly near the boundary between the Eurasian and African plates (Gulf of Cadiz, SW margin of Iberia). Mar. Geol. 155, 45-62.

Dewey, J.F., Pitman III, W., Ryan, W., Bonnin, J., 1973. Plate tectonics and the evolution of the Alpine System. Geol. Soc. Amer. Bull. 84, 3137-3180.

Dewey, J.F., Helman, M.L., Turco, E., Hutton, D.H.W., Knott, S.D., 1989. Kinematics of the western Mediterranean. In: Coward, M. (Ed.), Alpine Tectonics. Geol. Soc. London Spec. Publ., vol. 45, pp. 265-283.

Flinch, J.F., Bally, A.W., Wu, S., 1996. Emplacement of a passivemargin evaporitic allochthon in the Betic Cordillera of Spain. Geology 24, 67-70.

Fukao, Y., 1973. Thrust faulting at a lithospheric plate boundary: the Portugal earthquake of 1969. Earth Planet. Sci. Lett. 18, 205-216. 
González, A., Córdoba, D., Vegas, R., Matias, L.M., 1998. Seismic crustal structure in the southwest of the Iberian Peninsula and Gulf of Cadiz. Tectonophysics 296, 317-331.

Gràcia, E., Dañobeitia, J., Vergés, J., Bartolomé, R., Córdoba, D., 2003. Crustal architecture and tectonic evolution of the Gulf of Cadiz (SW Iberian margin) at the convergence of the Eurasian and African plates. Tectonics 22 ( $\left.{ }^{\circ} 4\right)$, 1033, doi:10.1029/2001TC901045.

Grimison, N.L., Chen, W.P., 1986. The Azores-Gibraltar plate boundary: focal mechanisms, depths of the earthquakes, and their tectonic implication. J. Geophys. Res. 91, 2029-2047.

Gutscher, M.-A., Malod, J., Rehauult, J.-P., Contrucci, I., Klingelhoefer, F., Mendes-Victor, L., Spakman, W., 2002. Evidence for active subduction beneath Gibraltar. Geology 30, 1071-1074.

Hayes, D.E., Pimm, A.C., Beckmann, J.P., Benson, W.E., Berger, W.H., Roth, P.H., Supko, P.R., Von Rad, U., 1972. Site 135. In: Pimm, A.C. (Ed.), Initial Reports of the Deep-Sea Drilling Project. JOIDES, vol. 14, pp. $15-48$.

Imperador-1, 1976. Final Well Site Report. Arquivo Gabinete para a Prospecção e Exploração de Petróleo, $n^{0}$ 21413- off/Chevron.

Kreiter, S., 1999. Analyse tectono-sédimentaire du Plio-Quaternaire du Golfe de Cadix. DEA Geosciences Marines, Ec. Doct. Sciences de la Mer, U.B.O., Brest, 56 p.

Lajat, D., Biju-Duval, B., Gonnard, R., Letouzey, J., Winnock, E., 1975. Prolongement dans l'Atlantique de la partie externe de l'Arc bético-rifain. Bull. Soc. Géol. France 7 (17), 481-485.

Le Gall, B., Piqué, A., Réhault, J.P., Specht, M., Malod, J., 1997. Structure et mise en place d'une ride océanique dans un contexte de limite de plaques convergentes: le Banc de Gorringe (SW Ibéria). C. R. Acad. Sci., Paris 325, 853-860.

Letouzey, J., Colletta, B., Vially, R., Chermette, J.C., 1996. Evolution of salt-related structures in compressional settings. In: Jackson, M. P.A., Roberts, D.G., Snelson, S. (Eds.), Salt Tectonics: A Global Perspective. AAPG Memoir, vol. 65, pp. 41-60.

Lopes, F.C., 2002. Análise tectono-sedimentar do Cenozóico da Margem Algarvia. PhD thesis, Universidade de Coimbra,. 593 pp.

Lopes, F.C., Cunha, P. Proença, 2000. Estratigrafia sísmica do Cenozóico na Plataforma Continental Algarvia: interpretação do controle tectónico da sedimentação. Ciênc. Terra (U.N.L.) 14, 257-276.

Lopes, F.C., Le Gall, B., Piqué, A., 1999. Tectónica cenozóica nos sectores central e oriental da Plataforma Continental Algarvia. Comun. Inst. Geol. Min. 86, 101-119.

Lotze, F., 1945. Zur Gliederung der Varisciden der Iberischen Meseta. Geoeckt Forsch 4, 78-92.

MacIntyre, R.M., Berger, G.W., 1982. A note on the geochronology of the Iberian Alkaline Province. Lithos 5, 133-136.

Maestro, A., Somoza, L., Medialdea, T., Talbot, C.J., Lowrie, A., Vásquez, J.T., Díaz-del-Rio, V., 2003. Large-scale slope failure involving Triassic and Middle Miocene salt and shale in the Gulf of Cadiz /Atlantic Iberian Margin. Terra Nova 15, 380-391.

Maldonado, A., Somoza, L., Pallarés, L., 1999. The Betic orogen and the Iberian-African boundary in the Gulf of Cadiz: geological evolution (central North Atlantic). Mar. Geol. 155, 9-43.

Malod, J.A., 1982. Comparaison de l'évolution des marges continentales au Nord et au Sud de la Péninsule Ibérique. Thése d'Etat, Mém. Sc. Terre, Univ. Paris VI, 235 pp.

Manuppella, G., 1988. Litoestratigrafia e tectónica da Bacia do Algarve. Geonovas 10, 67-71.

Manuppella, G., 1992. Carta Geológica da Região do Algarve, na escala 1:100 000. Notícia Explicatica. Serv. Geol. Portugal, Lisboa.

Mitchum Jr., R.M., Vail, P.R., 1977. Seismic stratigraphy and global changes of sea-level. Part. 7: seismic stratigraphic interpretation procedure. In: Payton, C.E. (Ed.), Seismic Stratigraphy -
Application to Hydrocarbon Exploration. A.A.P.G. Memoire, vol. 26, pp. 135-143.

Mitchum, R.M., Vail Jr., P.R., Sangree, J.B., 1977. Seismic stratigraphy and global changes of sea-level. Part. 6: stratigraphic interpretation of seismic reflection patterns in depositional sequences. In: Payton, C.E. (Ed.), Seismic Stratigraphy Application to Hydrocarbon Exploration. A.A.P.G. Memoire, vol. 26, pp. 117-133.

Mougenot, D., 1981. Une phase de compression au Crétacé terminal à l'Ouest du Portugal: quelques arguments. In Libro em homenagem ao Professor Carlos Teixeira. Bol. Soc. Geol. Port. 22, 233-239.

Mougenot, D., 1989. Geologia da Margem Portuguesa. Pub. (G)-IH192-DT, Tese, Univ. Pierre et Marie Curie, Paris VI, 259 pp.

Mougenot, D., Vanney, J.R., 1982. Les rides de contourites plioquaternaires de la pente continentale sud-portugaise. Coll. Intern, CNRS. Bull. Inst. Géol. Bassin Aquitaine 31, 131-139.

Moura, D., Boski, T., 1994. Ludo Formation — a new lithostratigraphic unit in Quaternary of central Algarve. Gaia 9, 95-98.

Moura, D., Boski, T., 1999. Unidades litostratigráficas do Pliocénico e Plistocénico no Algarve. Comun. Inst. Geol. Min. 86, 85-106.

Nelson, C.H., Baraza, J., Maldonado, A., 1993. Mediterranean undercurrent sandy contourites, Gulf of Cadiz, Spain. Sediment. Geol. 82, 103-131.

Nelson, C.H., Baraza, J., Maldonado, A., Rodero, J., Escutia, C., Barber, J., 1999. Influence of the Atlantic inflow and Mediterranean outflow currents on Late Quaternary sedimentary facies of Gulf of Cadiz continental margin. Mar. Geol. 155, 99-129.

Olivet, J.L., 1996. La Cinématique de la Plaque Ibérique. Bull. Centres Rech. Explor. - Prod. Elf Aquitaine 20, 131-195.

Pais, J., (in press). O Cenozóico do litoral algarvio: Ensaio de síntese. Sumário pormenorizado da Lição de Síntese para a obtenção do grau de Professor Agregado em Geologia (Estratigrafia e Paleontologia), Universidade Nova de Lisboa, 26 p.

Pais, J., Legoinha, P., Elderfield, H., Sousa, L., Estevens, M., 2000. The Neogene of Algarve (Portugal). Ciênc. Terra (U.N.L.) 14, 277-288.

Palain, C., 1976. Une série détritique terrigène. Les "Grès d.inférieur du Portugal”. Mem. Serv. Geol. Port. 25, 411 pp.

Pinheiro, L.M., Wilson, R.C.L., Pena dos Reis, R., Whitmarsh, R.B., Ribeiro, A., 1996. The western Iberia margin: a geophysical and geological overview. Proceedings of the Ocean Drilling Program. Scientifics Results, p. 149.

Rey, J., 1982. Le Crétacé dans la region de Faro (Algarve, Portugal). Comun. Serv. Geol. Port. 68, 225-236.

Rey, J., 1983. Le Crétacé de l'Algarve: essai de synthèse. Comun. Serv. Geol. Port. 69, 87-101.

Ribeiro, A., Antunes, M.T., Ferreira, M.P., Rocha, M.B., Soares, A.F., Zbyszewski, G., Moitinho de Almeida, F., Carvalho, D., Monteiro, J.H., 1979. Introduction à la Géologie Générale du Portugal. Serv. Geol. Port., Lisboa 114 pp.

Ribeiro, A., Kullberg, M.C., Kullberg, M.C., Manuppella, G., Phipps, S., 1990. A review of Alpine tectonics in Portugal: foreland detachment in basement and cover rocks. Tectonophysics 184, 357-366.

Roest, W.R., Srivastava, S.P., 1991. Kinematics of plate boundaries between Eurasia, Iberia and Africa in the North Atlantic from the Late Cretaceous to the Present. Geology 19, 613-616.

Ruivo-1, 1975. Evaluation Report. Arquivo Gabinete para a Prospecção e Exploração de Petróleo, n 21350- off/Chevron Oil Company of Portugal.

Ryan, W.B.R., Hsü, K.J., Cita, M.B., Dumitrica, P., Lort, J., Maync, W., Nestoref, W.D., Pautot, G., Stradner, H., Wezel, F.C., 1973. 
Site 120. In: Kaneps, A.G. (Ed.), Initial Reports of the Deep-Sea Drilling Project. JOIDES, vol. 13, pp. 19-41.

Sanz de Galdeano, C., 1990. Geologic evolution of Betic Cordilleras in the Western Mediterranean, Miocene to the present. Tectonophysics 172, 107-119.

Sanz de Galdeano, C., Rodríguez-Fernández, J., 1996. Neogene palaeogeography of the Betic Cordillera: an attempt at reconstruction. In: Friend, P.F., Dabrio, C.J. (Eds.), Tertiary Basins of Spain. The Stratigraphic Record of Crustal Kinematics. Cambridge University Press, pp. 323-329.

Sanz de Galdeano, C., Vera, J.A., 1991. Una propuesta de clasificatión de las cuencas neógenicas béticas. Acta Geol. Hisp. 26, 205-227.

Sartori, R., Torelli, L., Zitellini, N., Peis, D., Lodolo, E., 1994. Eastern segment of the Azores-Gibraltar line (central-eastern Atlantic): an ocean plate boundary with diffuse compressional deformation. Geology $22\left(\mathrm{n}^{\circ} 7\right), 555-558$.

Srivastava, S.P., Schouten, H., et al., 1990a. Iberian plate kinematics: a jumping plate boundary between Eurasia and Africa. Nature 344, 756-759

Srivastava, S.P., Roest, W.R., Kovacs, L.C., Oakey, G., Lévesque, S., Verhoef, J., Macnab, R., 1990b. Motion of the Iberia since the Late Jurassic: results from detailed aeromagnetic measurements in the Newfoundland Basin. Tectonophysics 184, 229-260.

Stow, D.A.V., Faugères, J.-C., Gonthier, E., 1986. Facies distribution and textural variation in Faro drift contourites: velocity fluctuation and drift growth. Mar. Geol. 72, 71-100.

Terrinha, P., 1998a. Structural geology and tectonic evolution of the Algarve Basin, south Portugal. PhD thesis, Imperial College, London, $430 \mathrm{pp}$.
Terrinha, P., 1998b. Neogene and Quaternary tectonic evolution of the south Portugal margin. Actas do V Congresso Nacional de Geologia, pp. D81-D84.

Terrinha, P., Coward, M.P., Ribeiro, A., 1990. Salt tectonics in the Algarve basin: the Loulé diapir. Comun. Serv. Geol. Port. 76, $33-40$.

Terrinha, P., Dias, R.P., Ribeiro, A., Cabral, J., 1999. The Portimão fault, Algarve basin, south Portugal. Comun. Inst. Geol. Miner. 86, 107-120.

Torrelli, L., Sartori, R., Zitelli, N., 1997. The Giant chaotic body in the Atlantic Ocean of Gibraltar: new results from a deep seismic reflection survey. Mar. Pet. Geol. 14, 125-138.

Tortella, D., Torne, M., Perez-Estaún, A., 1997. Geodynamic evolution of the eastern segment of the Azores-Gibraltar zone: the Gorringe Bank and the Gulf of Cadiz Region. Mar. Geophys. Res. 19, 211-230.

Udías, A., Arroyo, A.L., Mezcua, J., 1976. Seismotectonic of the Azores-Alboran region. Tectonophysics 31, 269-289.

Vanney, J.R., Mougenot, D., 1981. La plate-forme continentale du Portugal et des provinces adjacentes: analyse géomorphologique. Mem. Serv. Geol. Port. 28145 pp.

Vegas, R., Medialdea, T., Muñoz, M., Díaz del Río, V., Somoza, L., 2004. Nature and tectonic setting of the Guadalquivir Bank (Gulf of Cadiz, SW Iberian Peninsula). Rev. Soc. Geol. Esp. 17, 49-60.

Ziegler, P.A., 1989. Evolution of the North Atlantic - overview. In: Tankard, A.J., Balkwill, H.R. (Eds.), Extensional Tectonics and Stratigraphy of the North Atlantic Margins. AAPG Memoir, vol. 46, pp. 111-129. 